University of Nebraska - Lincoln

DigitalCommons@University of Nebraska - Lincoln

Camelina water use and seed yield response to irrigation scheduling in an arid environment

D. J. Hunsaker

USDA-ARS, doug.hunsaker@usda.gov

A. N. French

USDA-ARS, andrew.french@ars.usdag.gov

K R. Thorp

USDA-ARS, kelly.thorp@ars.usda.gov

Follow this and additional works at: https://digitalcommons.unl.edu/usdaarsfacpub

Hunsaker, D. J.; French, A. N.; and Thorp, K R., "Camelina water use and seed yield response to irrigation scheduling in an arid environment" (2013). Publications from USDA-ARS / UNL Faculty. 1259.

https://digitalcommons.unl.edu/usdaarsfacpub/1259

This Article is brought to you for free and open access by the U.S. Department of Agriculture: Agricultural Research Service, Lincoln, Nebraska at DigitalCommons@University of Nebraska - Lincoln. It has been accepted for inclusion in Publications from USDA-ARS / UNL Faculty by an authorized administrator of DigitalCommons@University of Nebraska - Lincoln. 


\title{
Camelina water use and seed yield response to irrigation scheduling in an arid environment
}

\author{
D. J. Hunsaker • A. N. French • K. R. Thorp
}

This article is a U.S. government work, and is not subject to copyright in the United States.

Received: 17 January 2012/ Accepted: 12 July 2012/Published online: 31 July 2012

(C) Springer-Verlag (outside the USA) 2012

\begin{abstract}
Camelina sativa (L.) Crantz is a promising, biodiesel-producing oilseed that could potentially be implemented as a low-input alternative crop for production in the arid southwestern USA. However, little is known about camelina's water use, irrigation management, and agronomic characteristics in this arid environment. Camelina experiments were conducted for 2 years (January to May in 2008 and 2010) in Maricopa, Arizona, to evaluate the effectiveness of previously developed heat unit and remote sensing basal crop coefficient $\left(K_{c b}\right)$ methods for predicting camelina crop evapotranspiration (ET) and irrigation scheduling. Besides $K_{c b}$ methods, additional treatment factors included two different irrigation scheduling soil water depletion (SWD) levels (45 and $65 \%)$ and two levels of seasonal $\mathrm{N}$ applications within a randomized complete block design with 4 blocks. Soil water content measurements taken in all treatment plots and applied in soil water balance calculations were used to evaluate the predicted ET. The heat-unit $K_{c b}$ method was updated and validated during the second experiment to predict ET to within $12-13 \%$ of the ET calculated by the soil water balance. The remote sensing $K_{c b}$ method predicted ET within $7-10 \%$ of the soil water balance. Seasonal ET from the soil water balance was significantly greater for the remote sensing than heat-unit $K_{c b}$ method and significantly greater for the 45 than $65 \%$ SWD level. However, final seed yield means, which varied from 1,500 to $1,640 \mathrm{~kg} \mathrm{ha}^{-1}$ for treatments, were not significantly
\end{abstract}

Communicated by S. O. Shaughnessy.

D. J. Hunsaker $(\bowtie) \cdot$ A. N. French · K. R. Thorp

USDA-ARS, Arid Land Agricultural Research Center,

Maricopa, AZ 85138, USA

e-mail: doug.hunsaker@ars.usda.gov different between treatments or years. Seed oil contents averaged $45 \%$ in both years. Seed yield was found to be linearly related to seasonal ET with maximum yield occurring at about $470-490 \mathrm{~mm}$ of seasonal ET. Differences in camelina seed yields due to seasonal $\mathrm{N}$ applications (69-144 $\mathrm{kg} \mathrm{N} \mathrm{ha}^{-1}$ over the 2 years) were not significant. Further investigations are needed to characterize camelina yield response over a wider range of irrigation and $\mathrm{N}$ inputs.

\section{Introduction}

Energy security issues, finite petroleum supplies, and the adverse environmental impacts associated with fossil-based transportation fuels have recently heightened interest in the development and production of carbon-neutral oilseed crops as biodiesel fuel alternatives (Pavlista et al. 2011). A promising oilseed crop that has received considerable attention is Camelina sativa, a member of the mustard (Brassicaceae) family. Camelina has been produced commercially as a biofeedstock in semiarid areas of Montana, USA, since 2006 (Pilgeram et al. 2007). In July 2011, the United States Department of Agriculture created a new Biomass Crop Assistance Program (BCAP) project area to expand the availability of camelina feedstock in the USA (www:greencarcongress.com/2011/07/). The BCAP has targeted expanding current camelina production in the United States of America (USA) by 20,000 ha in several western states by early 2012. Other areas in North America currently conducting research on camelina crop production include the states of Nebraska, South Dakota, Wyoming, Colorado, Kansas, and Minnesota in the USA (Pavlista and Baltensperger 2007; Gesch and Cermak 2011) and western Canada (Gugel and Falk 2006). 
Camelina is viewed as a desirable alternative biodiesel crop because of its apparent lower cost of production (i.e., water, fertilizer, pesticides, and seeding rate) relative to other more common oilseeds being produced, such as soybean, canola, and sunflower (Frohlich and Rice 2005; Pilgeram et al. 2007; Moser 2010; Pavlista et al. 2011). The oil content of the seed is typically near or greater than $40 \%$ (Zubr 1997; Berti et al. 2011), and the oil is made up of unsaturated fatty acids, including a 30-40\% fraction of linolenic acid, another 15-25\% fraction of linoleic acid, and about a $15 \%$ fraction of oleic acid (Zubr 2003; Vollmann et al. 2007; Pilgeram et al. 2007). Camelina seed yields at maturity were reported by Moser (2010) to range from 900 to $2,240 \mathrm{~kg} \mathrm{ha}^{-1}$. The biodiesel from camelina seed oil has also been shown to be of good quality (Bernardo et al. 2003) and has similar properties to that of canola (Frohlich and Rice 2005).

Most of the research reported in North America on the adaptation and cultivation of camelina has been conducted in the northern USA climes and Canada, where camelina is grown as a dryland winter or spring rotational crop (e.g., Putnam et al. 1993; Budin et al. 1995; Gugel and Falk 2006; Pilgeram et al. 2007; Gilbertson et al. 2007; Gesch and Cermak 2011). There is limited literature on camelina responses to fertilizer. Based on early research (e.g., Putnam et al. 1993), and an emphasis to minimize camelina inputs, soil residual levels of $\mathrm{N}$ and $\mathrm{P}$ were assumed to be adequate and fertilizers were not applied (Gesch and Cermak 2011). However, like other crops, adequate fertility is required to optimize yields. Comprehensive camelina agronomic trials conducted by Zubr (1997) in Denmark showed significant seed yield responses for $\mathrm{N}$ fertilizer applications from 70 to $130 \mathrm{~kg} \mathrm{~N} \mathrm{ha}^{-1}$. Zubr (1997) also recommended that about $30 \mathrm{~kg} \mathrm{P} \mathrm{ha}^{-1}$ be applied each season at sowing.

Recently, Pavlista et al. (2011) reported the use of sprinkler irrigation to supplement rainfall in studies on the growth and development of spring-planted camelina in western Nebraska, USA. Hergert et al. (2011), also in western Nebraska, used variable sprinkler irrigation rates in a four-year, two-location camelina (cv. Cheyenne) study to obtain a large range of seasonal water use response (205-525 mm), where seasonal water use was the seasonal crop evapotranspiration (ET) determined as the residual of the soil water balance. In the Hergert et al. (2011) studies, a linear camelina seed yield response was highly correlated with seasonal crop ET ( $r^{2}$ of 0.82$)$. Their water use efficiency (WUE, expressed as seed yield per unit ET) varied from about 0.47 to $0.53 \mathrm{~kg} \mathrm{~m}^{-3}$ for seasonal ET of 380 and $510 \mathrm{~mm}$, respectively. The Hergert et al. (2011) results suggest that camelina yields are highly responsive to water input, although the total ET for maximum yields (i.e., about $510 \mathrm{~mm}$ ) was appreciably lower than those reported for traditional oilseed crops grown in the same region, such as soybean and sunflower (cf. Aiken et al. 2011). In Arizona, USA, French et al. (2009) and Hunsaker et al. (2011) applied surface irrigation to study camelina's water use and yield response to irrigation in an arid environment. In that experiment (2006-2007), a fall-planted camelina (cv. Robinson) was grown under five levels of irrigation. Crop maturity occurred in mid-April. Because irrigation was terminated in early March, total seasonal ET only varied from a high of 371 to a low of 276 (Hunsaker et al. 2011). Unlike the western Nebraska experiments above, seed yield response was not correlated with seasonal ET and WUE was about $0.33 \mathrm{~kg} \mathrm{~m}^{-3}$. Thus, under this arid environment, camelina appeared to tolerate infrequent and limited irrigation, where seed yield declined only about $12 \%$ for a $26 \%$ reduction in either irrigation input or total ET.

A major objective of the 2006-2007 Arizona experiment was to develop camelina crop coefficient $\left(K_{c}\right)$ information compatible with the commonly used reference evapotranspiration $\left(\mathrm{ET}_{o}\right)$ method and procedures presented in the Food and Agriculture Organization (FAO), Irrigation and Drainage Paper No. 56 (FAO-56), Crop Evapotranspiration (Allen et al. 1998). A crop coefficient relates the actual ET of a crop at a given stage of development to the $\mathrm{ET}_{o}$ reference, calculated from meteorological data, that is, $\mathrm{ET}=K_{c} \times \mathrm{ET}_{o}$. Because of the effects of increased soil evaporation following irrigation or heavy rainfall, FAO-56 developed dual crop coefficient procedures to allow computation of more precise estimates of daily ET when wet soil occurs. The FAO-56 dual crop coefficient approach separates the $K_{c}$ into two coefficients, a basal crop coefficient, $K_{c b}$ (primarily crop transpiration), and a wet soil evaporation coefficient, $K_{e}$, to quantify the individual contributions for the two components of $\mathrm{ET}_{c}$. The dual procedures also include a water stress coefficient $\left(K_{s}\right)$ to quantify the effects of soil water stress on ET. The daily ET calculation for the dual approach is written as:

$\mathrm{ET}=\left(K_{c b} K_{s}+K_{e}\right) \mathrm{ET}_{o}$

where $K_{s}<1$ when the available soil water is insufficient for full ET and $K_{s}=1$ when there is no soil water limitation on ET.

Accurate and reliable estimations of crop ET are key inputs for determining proper irrigation scheduling (timing and water application depth). The most widely used ET estimation method for irrigation scheduling is the crop coefficient $\mathrm{ET}_{o}$ paradigm (Jensen and Allen 2000; Allen and Pereira 2009). Crop coefficient curves based on growth-related parameters, such as heat units, have been reported to more adequately account for the effects of climatic variability over time-based crop coefficients (Sammis et al. 1985; Slack et al. 1996; Howell et al. 2004). Improvements in ET estimation over time-based $K_{c b}$ curves 
can be realized by using remote sensing models of $K_{c b}$. Hunsaker et al. (2005, 2007) and Gonzalez-Dugo and Mateos (2008) illustrate the development and use of normalized difference vegetation index (NDVI) for estimating $K_{c b}$.

Data collected in a prior camelina experiment conducted during 2006-2007 in Arizona were used to develop camelina $K_{c b}$ models based on both heat units and remote sensing observations of NDVI (Hunsaker et al. 2011). In 2008 and 2010, the $K_{c b}$ models were used to guide irrigation scheduling in camelina experiments conducted in Arizona. The objectives of the present study were to evaluate the usefulness of these two $K_{c b}$ methods to predict crop ET for irrigation scheduling and to evaluate the effects of two different irrigation scheduling soil water depletion levels and two levels of $\mathrm{N}$ applications on the seed yield and oil contents of camelina in this arid environment.

\section{Materials and methods}

\section{Experimental site and Camelina planting}

Camelina field experiments were conducted for two growing seasons (January through May) in 2008 and 2010 on a 1.3-ha field site at The University of Arizona, Maricopa Agricultural Center (MAC) $\left[33^{\circ} 04^{\prime} \mathrm{N}, 111^{\circ} 58^{\prime} \mathrm{W}, 361 \mathrm{~m}\right.$ M.S.L.], in central Arizona. The field soil is mapped as a Casa Grande series (reclaimed fine loamy, mixed, superactive, hyperthermic, Typic Natriargid) having predominantly sandy clay loam texture (Post et al. 1988). Measurements of soil water retention were obtained on the field site in the 2006-2007 camelina experiment (Hunsaker et al. 2011). During the installation of the neutron access tubes in that experiment, soil samples in each of 38 plots were extracted in $0.3-\mathrm{m}$ increments to a depth of $1.8 \mathrm{~m}$. The soil samples were analyzed for $-33 \mathrm{kPa}$ (field capacity) and $-1,500 \mathrm{kPa}$ (wilting point) soil water retention using pressure membrane extractors. Following the 2006-2007 camelina experiment, cotton was grown on the site from May to October 2007. Following the 2008 camelina experiment, wheat was grown from December 2008 through June 2009. After the wheat harvest, the field site was fallow until the 2010 camelina experiment. Prior to each camelina experiment, the field site was laser-leveled to zero grade.

In early December 2007, prior to the 2008 experiment, residual soil $\mathrm{NO}_{3}-\mathrm{N}$ concentrations of the top $0.30 \mathrm{~m}$ were determined for multiple composite soil samples collected throughout the field. The residual soil $\mathrm{NO}_{3}-\mathrm{N}$ concentrations expressed in $\mathrm{kg} \mathrm{NO}_{3}-\mathrm{N} \mathrm{ha}^{-1}$ averaged 18.4 \pm 7.1. Following fertility recommendations of Zubr (1997), a presowing application of ammonium phosphate (16:20:0) was uniformly incorporated into the field's soil surface at rates of $36 \mathrm{~kg} \mathrm{~N} \mathrm{ha}^{-1}$ and $45 \mathrm{~kg} \mathrm{P} \mathrm{ha}^{-1}$ on 14 January 2008. For the 2010 experiment, a pre-sowing application of ammonium phosphate (16:20:0) was also uniformly incorporated into the field's soil surface at the rates of $36 \mathrm{~kg} \mathrm{~N} \mathrm{ha}^{-1}$ and $45 \mathrm{~kg} \mathrm{P} \mathrm{ha}^{-1}$ on January 7, 2010. The residual soil $\mathrm{NO}_{3}-\mathrm{N}$ in the top $0.30 \mathrm{~m}$ determined from multiple composite soil samples collected one day prior to this application averaged $24.6 \pm 10.1 \mathrm{~kg} \mathrm{NO}_{3}-\mathrm{N} \mathrm{ha}^{-1}$. Camelina sativa (cv. Robinson), the same cultivar used in the 2006-2007 experiment, was broadcast-planted and packed in dry soil to 38 treatment plots (described below), as well as to other areas within the field, on January 16 , 2008 and on January 12, 2010 at seeding rates of 9.3 and $9.0 \mathrm{~kg}$ seed ha ${ }^{-1}$, respectively.

\section{Treatment structure and statistical design}

Thirty-two plots (each 12.2 by $18 \mathrm{~m}$ ) were arranged in the field in a $2 \times 2 \times 2$ factorial in a randomized complete block design (RCBD) with four blocks (Fig. 1). The experimental treatment factors (Table 1) consisted of two $K_{c b}$ estimation methods, designated as the FAO $(\mathrm{F})$ and the vegetation index (VI) methods; two levels of seasonal $\mathrm{N}$ application, designated as the High $(\mathrm{H})$ and Low (L) levels; and two irrigation scheduling soil water depletion (SWD) levels, designated as the A and B SWD levels. The randomization of treatments was identical in both years. The $K_{c b}$ methods will be described later in a section on treatment crop coefficient methods. The High $\mathrm{N}$ treatment in the 2008 experiment received a total seasonal application of $102 \mathrm{~kg} \mathrm{~N} \mathrm{ha}^{-1}$ given in three applications: (1) preplant, (2) at about the 4 leaf stage (February 21), and (3) at early flowering (March 31-April 9). The Low $\mathrm{N}$ treatment in 2008 received a total seasonal application of $69 \mathrm{~kg} \mathrm{~N} \mathrm{ha}^{-1}$, given at the same time as the first two applications to the $2008 \mathrm{H}$ treatment. For 2010, both the $\mathrm{H}$ and L N treatments received higher seasonal $\mathrm{N}$ applications than in 2008, 144 and $108 \mathrm{~kg} \mathrm{~N} \mathrm{ha}^{-1}$, respectively. These higher $\mathrm{N}$ levels in 2010 were imposed to evaluate whether or not camelina yields responded to total $\mathrm{N}$ greater than $\approx 100 \mathrm{~kg} \mathrm{~N} \mathrm{ha}^{-1}$, as suggested in field studies by Zubr (1997). The high $\mathrm{N}$ treatment for 2010 received four applications: (1) preplant, (2) at about the 8 leaf stage (February 26), (3) before flowering (March 15-25), and (4) at early fruit formation (April 05-10). The Low $\mathrm{N}$ treatment for 2010 received the first three applications as given to the High $\mathrm{N}$ treatment. The A and B SWD levels were 45 and $65 \%$, respectively, and were imposed to change the irrigation frequency for $A$ and B plots. By calculating the soil water balance equation over the effective crop root zone (Martin and Gilley 1993), irrigations for A plots were given when the SWD of the total available water (TAW) of the estimated crop root zone exceeded $45 \%$ and irrigations for B plots were given 


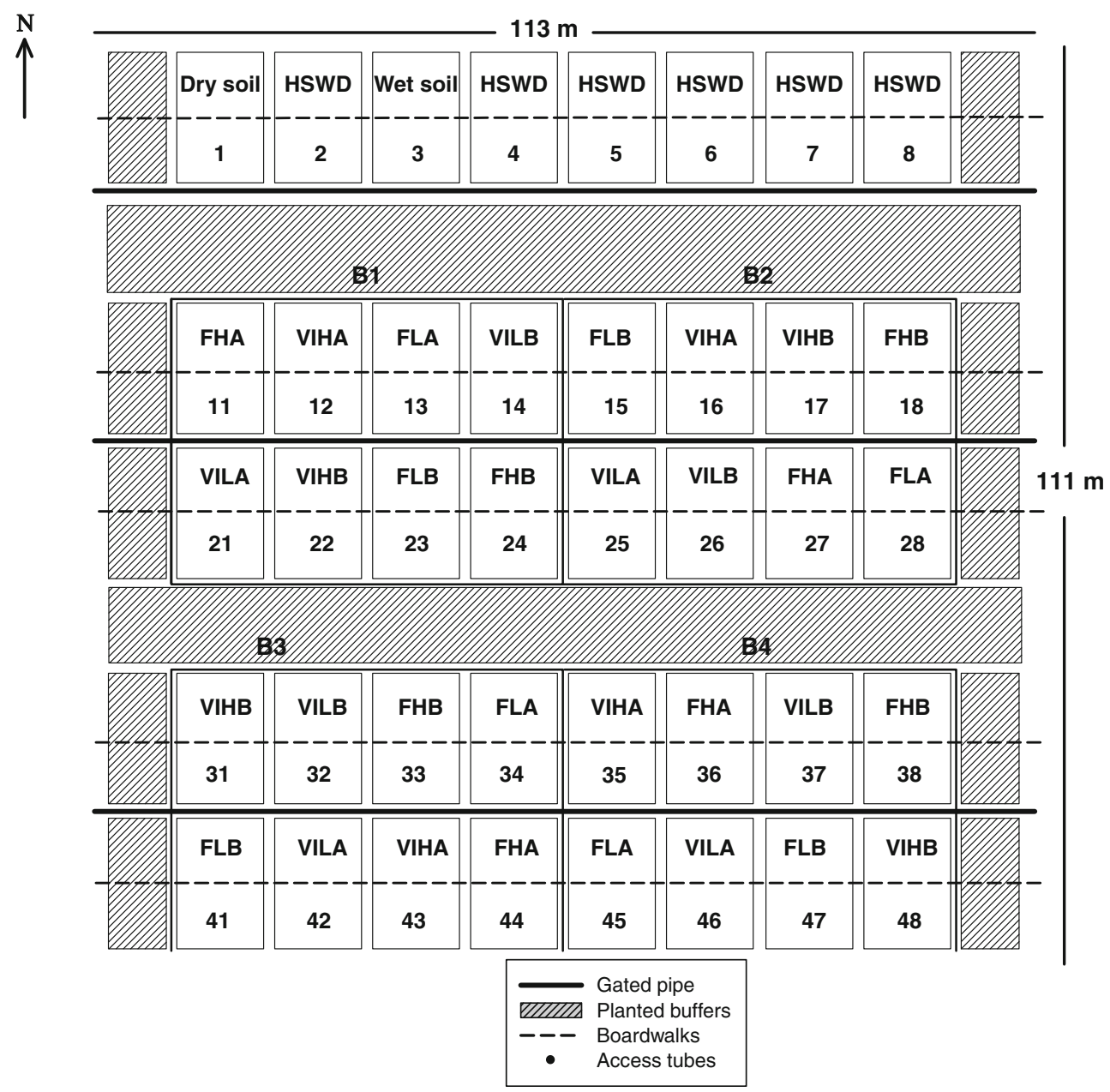

Fig. 1 Camelina experiment field site at Maricopa, Arizona, showing 40 plots, each $10 \mathrm{~m} \times 17 \mathrm{~m}$. Acronyms (defined in Table 1) shown at the top of each plot correspond to the particular subtreatment for the plot within the $2 \times 2 \times 2$ factorial. The eight subtreatments were randomized in four blocks (B1, B2, B3, and $\mathrm{B} 4)$. The top row at the north of the site includes six high soil water depletion (HSWD) plots that were not included in the randomized complete block design
Table 1 Summary of experimental treatments for the 2008 and 2010 camelina experiments at Maricopa, Arizona

Six higher soil water depletion (HSWD) plots were studied in the experiments, but were not included in the experimental block design

\begin{tabular}{|c|c|c|c|c|}
\hline \multirow[t]{2}{*}{ Subtreatment acronym } & \multicolumn{4}{|c|}{ Experimental treatments } \\
\hline & $K_{c b}$ method & Nitrogen level & SWD level & No. of replicates \\
\hline FHA & FAO $(\mathrm{F})$ & High $(\mathrm{H})$ & $45 \%(\mathrm{~A})$ & 4 \\
\hline FLA & FAO $(\mathrm{F})$ & Low (L) & $45 \%(\mathrm{~A})$ & 4 \\
\hline FHB & FAO (F) & High $(\mathrm{H})$ & $65 \%$ (B) & 4 \\
\hline FLB & FAO $(\mathrm{F})$ & Low (L) & $65 \%(\mathrm{~B})$ & 4 \\
\hline VIHA & VI & High $(\mathrm{H})$ & $45 \%(\mathrm{~A})$ & 4 \\
\hline VILA & VI & Low (L) & $45 \%(\mathrm{~A})$ & 4 \\
\hline VIHB & VI & High $(\mathrm{H})$ & $65 \%$ (B) & 4 \\
\hline VILB & VI & Low (L) & $65 \%(\mathrm{~B})$ & 4 \\
\hline
\end{tabular}

when it exceeded $65 \%$. The SWD levels imposed were the same in each experiment.

Treatment effects were statistically analyzed for measured camelina growth and seed yield data, seasonal irrigation application, and crop ET using a RCBD model within the Proc Mixed procedures of SAS (SAS Institute Inc 2009). Data from 2008 and 2010 were first analyzed separately in the RCBD model that included the fixed 
treatment effects: $K_{c b}$ method, N level, SWD level, and the first- and second-order fixed effects interactions. Block was considered a random effect. The data for the two experiments were also combined and analyzed as an RCBD fixed effects model that included block and year as random effects. Differences among fixed treatment means and fixed treatment interactions were evaluated at the 0.05 probability level. The COVTEST option in Proc Mixed was used to test random effects variance components.

Eight other plots (plots 1-8) shown along the northern strip of the field site (Fig. 1) were not included in the RCBD analyses, but were used for other experimental purposes. Plots 1 and 3 were unplanted, dry, and wet soil plots, respectively. The remaining plots $(2,4,5,6,7$, and 8 in Fig. 1) were planted plots subjected to higher SWD $(82 \%)$ than the B treatment plots. These plots designated as higher soil water depletion (HSWD) plots were based on the FAO $K_{c b}$ method to estimate SWD. In 2008, plots 2, 6, and 7 received a seasonal $\mathrm{N}$ application of $102 \mathrm{~kg} \mathrm{~N}^{-1}$, whereas plots 4, 5, and 8 received $69 \mathrm{~kg} \mathrm{~N} \mathrm{ha}^{-1}$. In 2010, all HSWD plots received a seasonal $\mathrm{N}$ application of $72 \mathrm{~kg} \mathrm{~N} \mathrm{ha}^{-1}$. Data from the HSWD plots will be presented in the paper for reference purposes. Planted buffer areas on the east-west sides of the field and alleyways between plots north to south (Fig. 1) provided cropped surfaces outside of plot areas.

\section{Camelina post-plant operations and crop emergence}

Following the planting of the 2008 experiment, neutron access tubes were installed in the field between January 17 and 24. The tubes were installed in all 38 plots to a depth of $2.0 \mathrm{~m}$ in a central area of the plot at a distance approximately $1.0 \mathrm{~m}$ from the plot center (Fig. 1). Irrigation border dikes were then formed on the four sides of each plot. Raised boardwalks on concrete blocks across the center of the plots provided non-destructive access (Fig. 1). Three gated pipe irrigation systems, $152-\mathrm{mm}$ in diameter, were installed in the $\mathrm{E}-\mathrm{W}$ direction extending the length of the field (Fig. 1). Irrigation water was controlled by an alfalfa valve located at the west end of each gated pipe system and gated ports spaced $1.02 \mathrm{~m}$ along the pipe were used to control water delivery to individual plots. The irrigation volume for each irrigation event was measured with calibrated in-line propeller-type water meters placed at the head of each gated pipe system. Irrigation water was gravity-fed to the alfalfa valves from a nearby storage reservoir at MAC. Field-calibrated neutron moisture meters were used to measure the volumetric soil water contents from 0.1 to $1.9 \mathrm{~m}$ in $0.2 \mathrm{~m}$ incremental depths. Initial soil water contents were collected on January 25, 2008. Soil water content measurements were taken on another 20 days throughout the season through May 12 .
Measurements for water content included dates one day before or on the day irrigation water was applied to any treatment and then again three to four days after the irrigation. On January 27, $17 \mathrm{~mm}$ of rain wetted up the soil to initiate germination of the dry camelina seed (Table 2). To obtain uniform crop emergence and stand establishment, all plots (including the HSWD plots) were irrigated four times between January 30 and March 7, 2008 (Table 2). Similarly, before $\mathrm{N}$ treatments were begun, all plots in 2008 were uniformly fertilized on February 21 with a $\mathrm{N}$ application of $33 \mathrm{~kg} \mathrm{~N} \mathrm{ha}^{-1}$ by injecting $32 \%$ solution ureaammonium-nitrate (UAN) through the irrigation system. After crop establishment in 2008, the HSWD plots were irrigated one more time on April 9 (Table 2). Seasonal N applications were $102 \mathrm{~kg} \mathrm{~N} \mathrm{ha}^{-1}$ for half of the HSWD plots (2, 6, and 7 in Fig. 1) and $69 \mathrm{~kg} \mathrm{~N}$ ha $^{-1}$ for plots 4, 5, and 8.

Unlike 2008, the threat of significant rain occurring before neutron access tubes could be installed in 2010 led to a decision to first irrigate the camelina and then install access tubes after germination. Thus, all plots were uniformly irrigated with $80 \mathrm{~mm}$ of water on January 15, 2010 (Table 2). Soil water contents were initiated on February 8 and then measured on 18 more days throughout the season though May 10. Incremental soil water content measurements were the same as for 2008. Before irrigation and $\mathrm{N}$ treatment differences were started in 2010, irrigation $(48 \mathrm{~mm})$ and $\mathrm{N}\left(36 \mathrm{~kg} \mathrm{~N} \mathrm{ha}^{-1}\right)$ were uniformly applied to all plots on February 26. After crop establishment, the HSWD plots were irrigated one more time on April 2 (Table 2). Seasonal $\mathrm{N}$ application was $72 \mathrm{~kg} \mathrm{~N} \mathrm{ha}^{-1}$ for all HSWD plots in 2010.

\section{Treatment crop coefficient methods}

Estimated daily ET was calculated with Eq. 1 and related FAO-56 dual crop coefficient procedures using two methods of $K_{c b}$ estimation: 1) a uniform $K_{c b}$ curve applied to all 16 FAO subtreatment plots and 2) individual NDVI-based $K_{c b}$ estimates for each VI plot. Measured daily meteorological data, including solar radiation, air temperature, wind speed, humidity, and rainfall were used to compute daily values for the grass-reference evapotranspiration $\left(\mathrm{ET}_{o}\right)$ using the FAO-56 Penman-Monteith equation (Allen et al. 1998). The data were provided by the University of Arizona, AZMET weather station (Brown 1989) that was located approximately $100 \mathrm{~m}$ from the field site. For the FAO $K_{c b}$ method, the daily $K_{c b}$ was estimated as a sixthorder sinusoidal curve driven by cumulative growing degree days (CGDD). Daily camelina GDD was expressed in degrees centigrade day $\left({ }^{\circ} \mathrm{C} \mathrm{d}\right)$, calculated by the sine curve method (Brown 1991) using an upper air temperature threshold of $30{ }^{\circ} \mathrm{C}$, and an air temperature base of $4.4{ }^{\circ} \mathrm{C}$, 


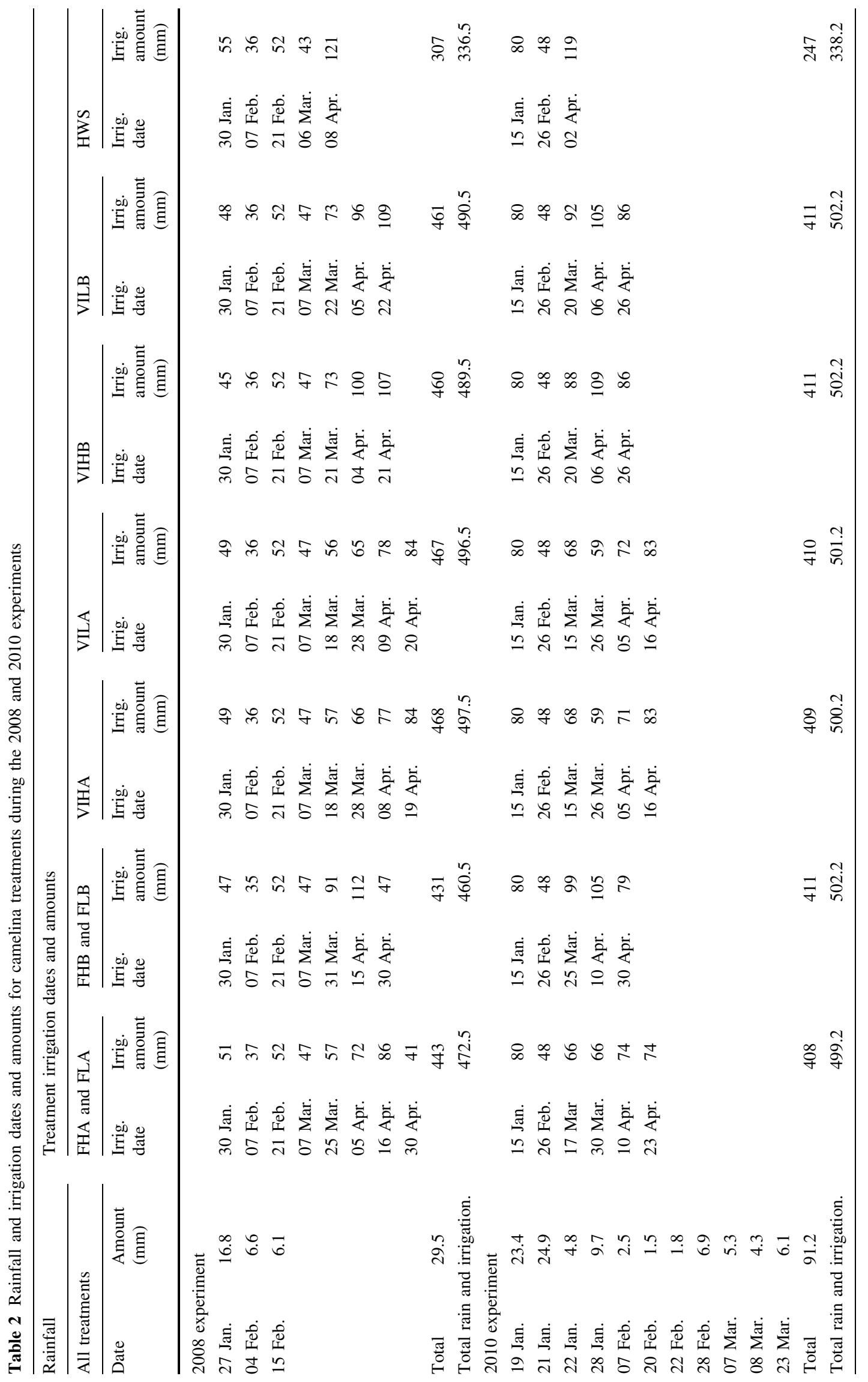


respectively. The total CGDD for the crop to reach physiological maturity was estimated at $1,300{ }^{\circ} \mathrm{C}$ d. For the VI $K_{c b}$ method, the $K_{c b}$ data were derived as a third-order polynomial function of NDVI. The models for both $K_{c b}$ methods were derived from data collected by Hunsaker et al. (2011) during a 2006-2007 camelina experiment in Maricopa, Arizona. The use of this particular CGDD $K_{c b}$ model for the 2008 FAO method provided a test to evaluate its effectiveness for winter-planted camelina, though the model was developed from the data for a fall-planted crop. An updated CGDD-based $K_{c b}$ curve was used for the FAO method in the 2010 camelina experiment. Details of the revised CGDD model will be presented in the Results and Discussion section. The same NDVI-based $K_{c b}$ model was used for VI plots in both the 2008 and 2010 experiments.

Camelina canopy reflectance measurements

In both 2008 and 2010, canopy reflectance was measured in all plots about twice per week from crop emergence until about 14 days prior to camelina harvest. Measurements were taken using a 4-band Exotech hand-held radiometer (Model BX-100; Exotech, Inc., Gaithersburg, MD) ${ }^{1}$ equipped with $15^{\circ}$ field-of-view optics, held in a nadir orientation, 1.5-2.0 $\mathrm{m}$ above the soil surface. Data were collected at a morning time period corresponding to a nominal solar zenith angle of $57^{\circ}$. For each plot, 24 reflectance observations were averaged across a 6-m transect along the north edge of the final harvest area (south of boardwalks, Fig. 1). Reflectance in the red (0.61-0.68 $\mu \mathrm{m})$ and near infrared (NIR, 0.79-0.89 $\mu \mathrm{m}$ ) wavebands was computed as the ratio of target radiance to time-interpolated values of solar irradiance inferred from frequent measurements of a calibrated, 0.6 by $0.6 \mathrm{~m}, 99 \%$ Spectralon $^{\mathrm{TM}}$ reference panel (Labsphere, Inc., North Sutton, NH, USA). The NDVI was computed as:

$\mathrm{NDVI}=(\mathrm{NIR}-\mathrm{red}) /(\mathrm{NIR}+\mathrm{red})$

Reflectance measurements obtained on days when there was cloud interference with the direct beam solar insolation or when soils were wet from irrigation or rainfall were not used in computations. The NDVI data for each plot were interpolated linearly, generating a daily NDVI curve up to the most recent acceptable measurement. A weighted linear regression model based on the four most recent NDVI measurements was used for projecting daily NDVI for days past the last measurement, so that future irrigation scheduling could be planned.

\footnotetext{
${ }_{1}^{1}$ Mention of trade names or commercial products in this publication is for the purpose of providing specific information and does not imply endorsement or recommendation by the U.S. Department of Agriculture.
}

Camelina ET and soil water balance estimation

In addition to $K_{c b}$ and $\mathrm{ET}_{o}$, estimating daily $\mathrm{ET}$ with Eq. 1 requires daily values of the $K_{e}$ and $K_{s}$ coefficients. Both of these coefficients were calculated using FAO-56 procedures. The soil parameters used in calculating $K_{e}$ were based on measured soil water retention properties from the 0 to $0.3 \mathrm{~m}$ depth obtained in the 2006-2007 experiment. The canopy fractional cover and crop height estimates required for calculating $K_{e}$ followed estimation procedures of FAO-56, where both were increased during the season proportionately with $K_{c b}$. The soil waterholding capacities needed for the estimation of $K_{s}$ were based on measured field capacity and wilting point within the entire soil profile. The effective root depth for camelina was estimated to increase to a maximum depth of $1.4 \mathrm{~m}$ based on the analyses of soil water extraction made in 2006-2007 (Hunsaker et al. 2011). To estimate $K_{s}$ and soil water depletion throughout the growing seasons for the 2008 and 2010 experiments, a root depth expansion model based on cumulative GDD was developed from the 2006-2007 data.

The soil water balance to determine the daily soil water depletion (expressed in $\mathrm{mm}$ ) of the root zone was calculated as:

$D_{r, i}=D_{r, i-1}+\mathrm{ET}_{i}-I_{i}-R_{i}+\mathrm{DP}_{i}$

where $D_{r, i-1}$ and $D_{r, i}$ are the soil water depletion (mm) of the effective root zone on the end of the previous day and the end of day $\mathrm{i}$, respectively, $\mathrm{ET}_{i}$ is the crop ET $(\mathrm{mm})$ on day $i$, and $I_{i}, R_{\mathrm{i}}$, and $\mathrm{DP}_{i}$ are the depth of irrigation applied $(\mathrm{mm})$, rainfall $(\mathrm{mm})$, and the deep percolation (mm) that occurred on day i, respectively. For the VI treatments for 2008 and 2010, the daily root zone soil water balance was calculated separately for each of the individual VI plots, that is, each plot had a unique $K_{c b}$ as determined from NDVI, unique soil water retention properties determined from soil analyses, and unique irrigation depths determined from flow meters. On the other hand, the daily soil water balance was calculated assuming a uniform $K_{c b}$ model (GDD model) for all FAO plots. Two soil water balance calculations were made for the FAO treatments, one for the A plots and one for the B. Soil water parameters used in the ET and soil water balance calculations were based on the average soil water properties within each group (i.e., A and B). To initiate the root zone water balance (Eq. 3), $D_{r, i}$ was estimated from volumetric soil water content measurements taken for plots at the beginning of the 2008 season (i.e., January 25), whereas depletion was estimated to be slightly greater than zero for all plots following the start-up $80 \mathrm{~mm}$ irrigation on January 15. 
Treatment irrigation scheduling

The TAW within the effective root zone is the difference between the field capacity and wilting point (Allen et al. 1998). Irrigations for treatment plots were scheduled for the day after calculated $D_{r, i}$ when expressed as a percentage of TAW (i.e., as $\mathrm{SWD}_{p, i}$ in Eq. 4) exceeded 45 and $65 \%$ of the TAW for treatment plots within the A and B groups, respectively. A soil depletion fraction, $p$, of 0.6 (i.e., $60 \%$ ) was used in the FAO-56 procedures to allow a slight reduction in estimated $\mathrm{ET}\left(K_{s}<1\right)$ prior to irrigations for B plots. Calculation of $\mathrm{SWD}_{p}$ for any day $i$ was expressed as:

$\mathrm{SWD}_{p, i}=100 \times\left[D_{r, i} / \mathrm{TAW}_{i}\right]$

Irrigation amounts for all plots replaced $100 \%$ of the estimated $D_{r, i}$ at the time of irrigation, plus an additional $5-10 \%$ to account for inefficiencies in the irrigated water distribution. For both seasons, all FAO subtreatment plots (within the A or B SWD level) were irrigated on the same days and with approximately equal amounts of water. Table 2 shows the average irrigation depth applied to subtreatments by date during 2008 and 2010. Due to the different levels of allowable SWD, irrigations applied to the A treatment for either $K_{c b}$ method were generally more frequent but lighter in volume than those applied to $\mathrm{B}$ treatment (Table 2). As mentioned earlier, irrigations were scheduled individually for each of the VI plots, based on the estimated soil water depletion of the individual plot.

\section{Supporting field measurements}

Camelina stand counts were made in all plots on February 27, 2008, and on February 16, 2010, about 25 days after crop emergence in each season. Plant populations were determined by counting all emerged plants within six, $0.3 \mathrm{~m}$ by $0.3 \mathrm{~m}$ areas located in a designated final harvest area of each plot. Weekly photographic data were collected at midfield locations for all plots (south of the boardwalks, Fig. 1) to document actual camelina fractional crop cover. A digital camera (Powershot G2, Canon USA, Inc., Lake Success, $\mathrm{NY}$ ) was mounted at the end of a 2.6-m hand-held aluminum pole, allowing nadir views for all plots with a field of view of about $1.6 \mathrm{~m} \times 1.2 \mathrm{~m}$. Pixel resolution was better than $1 \mathrm{~mm}$ at mid-season canopy heights of about $0.5 \mathrm{~m}$. Image data were originally collected in raw mode and then were converted to three-band (red, green, and blue) TIFF format. Weekly fractional crop cover estimates for each plot were generated using a green index classification method developed and presented by French et al. (2009). Weekly camelina plant heights were measured for all plots in 2008 from March 14 to April 24 and in 2010 from March 1 to April 26. Plant height measurements were begun when plants were about $0.1 \mathrm{~m}$ and $0.07 \mathrm{~m}$ tall for 2008 and 2010 , respectively. Plant heights were measured using a meter stick in approximately the same six locations where stand counts were measured. Growth stage observations for all plots were made on a biweekly basis. On May 27-28 in 2008 and on May 26 in 2010, seed yield samples were harvested from each plot using a Hege plot combine (Wintersteiger AG, Austria) equipped with a 2.4-m cutter bar. The samples were harvested within designated areas measuring approximately $24 \mathrm{~m}^{2}$ in the south half of each plot (south of the boardwalk in Fig. 1). Each harvested plot area was individually marked and measured for total area. Subsamples of seed for each plot were weighed and then dried to approximately 3-4\% moisture. Final seed yield was expressed at $8.0 \%$ seed moisture content (Vollmann et al. 2007). Oil content, expressed on a dry weight basis, was determined on $0.5 \mathrm{~g}$ of seed for each plot using a TDNMR mini-spectrometer (Model mq20, Bruker Optics Inc., Billerica, MA). Total $\mathrm{N}$ was also analyzed on a dry weight basis on another $0.5 \mathrm{~g}$ sample of seed for each plot using a CN analyzer (Carlo Erba, NA 1500 Series 2, Milan, Italy).

\section{Camelina ET and $K_{c b}$ derived from measurements}

Field data were used to evaluate the performance of the crop coefficient and ET estimation employed in treatment irrigation scheduling. Soil water content measurements provided data to calculate ET rates for each plot. The procedures used to calculate ET from water balance measurements were also described in Hunsaker et al. (2011). Briefly, estimates of camelina ET for plots were calculated approximately weekly as the residual of the soil water balance described by Martin and Gilley (1993). The estimates were calculated using the change in soil water storage (S) measured on two adjacent dates over the entire measurement depth of $1.9 \mathrm{~m}$, accounting for water gains in the soil profile from irrigation (I) and rainfall (R). Note that there was no runoff of water from the diked plots and no evidence of soil water movement below $1.7 \mathrm{~m}$. Thus, the ET in $\mathrm{mm}$ that occurred over two successive soil water measurement dates was calculated as:

$\mathrm{ET}=S 1-S 2+I+R$

where $S 1$ and $S 2$ are the soil water storages within the effective root depth measured on the first and second measurement dates, respectively, and I and $\mathrm{R}$ are the depths of irrigation and rainfall measured between the dates, respectively, where all variables are in $\mathrm{mm}$. The weekly ET data for a given plot were then combined with the weekly measured crop height and canopy cover and the soil water parameters for the plot to back-calculate weekly basal crop coefficients. The calculation was made by rearranging Eq. 1 and solving for $K_{c b}$ (Hunsaker et al. 2005). 
Paired-sample $t$ tests were performed using SAS Proc Ttest (SAS Institute Inc. 2009) to test for significant differences between predicted ET that was used in the irrigation scheduling experiments and the measured ET determined from the water balance. The ET prediction was also assessed using statistical evaluation parameters that included mean absolute error (MAE) and mean absolute percent difference (MAPD), as described by Paul et al. (2004) and Wang et al. (2009), respectively, the coefficient of determination $\left(r^{2}\right)$, and The Nash-Sutcliffe coefficient of efficiency, $E$ (Nash and Sutcliffe 1970) to evaluate goodness of fit.

\section{Results and discussion}

Camelina development characteristics and growing season climate

Initiation of the camelina crop with watering for each year occurred on January 27, 2008 and January 15, 2010. There was visible emergence of seedlings on February 4, 2008 and on January 21, 2010, respectively. Mean plant population density for the individual subtreatment plots varied from 288 to 312 plants $\mathrm{m}^{-2}$ and from 257 to 307 plants $\mathrm{m}^{-2}$ in 2008 and 2010, respectively (Fig. 2). Plant density was not significantly different between years, $K_{c b}$ method, $\mathrm{N}$ level, or SWD level. Camelina flowering started 20-21 March in both seasons, and the crop continued flowering through approximately April 21, 2008 and April 15, 2010. Physiological maturity of plants (brown stems, pods, and leaves) was on May 11 and 9 for 2008 and 2010, respectively. In both camelina seasons, there were no weed or insect pressures and pesticides were not needed.

Cumulative monthly and season totals of rainfall, $\mathrm{ET}_{o}$, and GDD are shown for the 2008 and 2010 camelina experiments in Table 3. The climate data presented were determined from January 27 to May 11 for 2008 (106 days) and from January 15 to May 9 for 2010 (115 days), that is, from crop initiation to physiological maturity for each growing season. Long-term climate averages at Maricopa (1989 through 2007) for the months of January and May are presented for the same dates as for 2010 in Table 3. The month of January was notably wetter in 2010 compared to the long-term average in Maricopa. Total seasonal rainfall was also about $60 \mathrm{~mm}$ higher for 2010 than 2008, though the majority of seasonal rain occurred during the month of January in 2010. The monthly $\mathrm{ET}_{o}$ was greater during March, April, and May in the 2008 than 2010, whereas monthly $\mathrm{ET}_{o}$ for those months in 2010 was comparable to the long-term average $\mathrm{ET}_{o}$ (Table 3). Season total $\mathrm{ET}_{o}$ was also greater by $29 \mathrm{~mm}$ for 2008 than 2010 , even through the 2008 growing season was shorter than

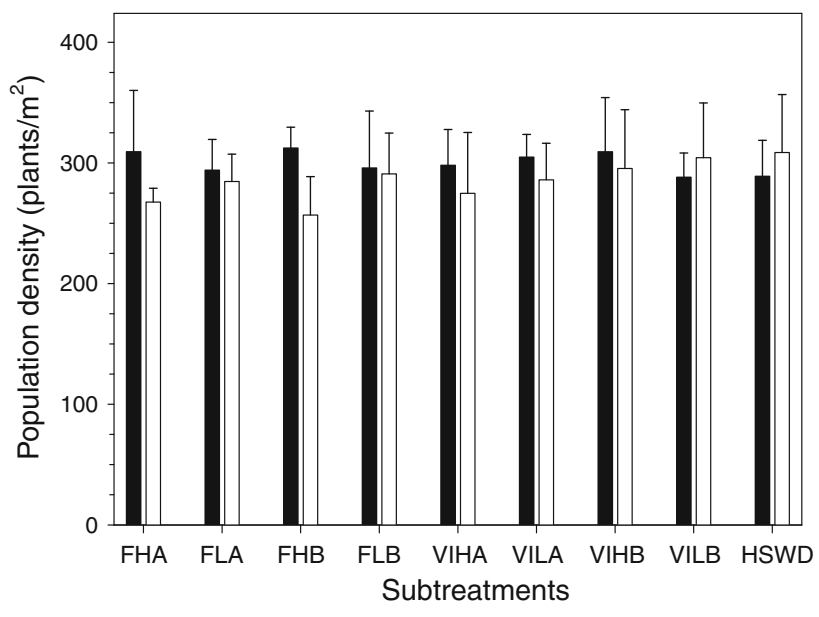

Fig. 2 Final plant density means shown for the eight subtreatments measured on February 27 in the 2008 experiment and on February 16 in the 2010 experiment. Error bars indicate the standard deviation of the plot replicates within each subtreatment. Average plant density for HSWD plots is also shown for each experiment

that in 2010. Similarly, monthly cumulative GDD for March, April, and May was greater in 2008 than 2010. However, the cumulative total GDD for the two seasons was about the same due to $100{ }^{\circ} \mathrm{C}$ d more GDD in 2010 than 2008 during the month of January.

Means of measured camelina crop height, green plant cover percentage, and NDVI are shown with time for individual subtreatments for 2008 and 2010 in Fig. 3. In both the 2008 and 2010 experiments, mean final crop heights (measured on April 24, 2008 and on April 26, 2010) were significantly greater for the VI than the FAO $K_{c b}$ method and for the A than the B SWD level. The effect of $\mathrm{N}$ level on crop height was not significant, nor was the variance component for year. Differences in green canopy development due to treatments only occurred in 2008 (Fig. 3e, f). During mid-to-late March in 2008, the effects of less frequent irrigation on green canopy cover were apparent for subtreatments under the B SWD level. The decreased canopy coverage at those times coincides with high soil water deficits and some visible plant wilting, particularly for the B subtreatment plots FHB and FLB. Maximum green canopy cover occurred approximately in mid-April for all subtreatments in 2008, and treatment means for maximum cover were not significantly different between the A and B SWD level. Thus, as the 2008 season progressed, B subtreatment canopies eventually recovered from the earlier stress period. However, maximum green canopy was affected by $\mathrm{N}$ level in 2008 , where mean canopy cover was significantly greater for $\mathrm{H}$ than the $\mathrm{L}$ treatment. The treatment differences noted for canopy cover are fairly well represented by the remotely sensed NDVI data (Fig. 3i through 1), though NDVI differences were less marked. 
Table 3 Monthly and season total rainfall, reference evapotranspiration (ET ${ }_{o}$, and growing degree days (GDD) for 2008 and 2010 camelina experiments, and the long-term average of variables at the Maricopa Agricultural Center, Maricopa, Arizona

\begin{tabular}{|c|c|c|c|c|c|c|c|c|c|}
\hline \multirow[t]{2}{*}{ Period } & \multicolumn{3}{|c|}{ Rainfall (mm) } & \multicolumn{3}{|c|}{$\mathrm{ET}_{o}(\mathrm{~mm})$} & \multicolumn{3}{|c|}{ Growing degree days, GDD $\left({ }^{\circ} \mathrm{C} \mathrm{d}\right)$} \\
\hline & 2008 & 2010 & $\begin{array}{l}\text { Long-term } \\
\text { average }^{\mathrm{a}}\end{array}$ & 2008 & 2010 & $\begin{array}{l}\text { Long-term } \\
\text { average }\end{array}$ & 2008 & 2010 & $\begin{array}{l}\text { Long-term } \\
\text { average }\end{array}$ \\
\hline Jan. $^{\mathrm{b}}$ & 16.8 & 63.0 & 6.6 & 9.8 & 32.2 & 38.2 & 30.5 & 131.1 & 119.1 \\
\hline Feb. & 12.7 & 12.7 & 21.3 & 74.6 & 73.0 & 81.9 & 234.1 & 240.1 & 233.8 \\
\hline Mar. & 0 & 15.8 & 21.4 & 147.0 & 130.5 & 133.1 & 382.7 & 336.7 & 345.6 \\
\hline Apr. & 0 & 0 & 7.9 & 204.1 & 182.9 & 183.7 & 454.4 & 405.7 & 442.8 \\
\hline May $^{\mathrm{c}}$ & 0 & 0 & 1.0 & 80.7 & 68.6 & 67.2 & 172.0 & 145.5 & 162.1 \\
\hline Total & 30 & 91 & 58 & 516 & 487 & 504 & 1274 & 1,259 & 1,303 \\
\hline
\end{tabular}

Long-term average data are the same as 2010 for the months of January and May

${ }^{\text {a }}$ Long-term average for indicated periods are from years 1989 to 2007, AZMET weather station, Maricopa Agricultural Center

b January data start from the first watering of dry-planted seed, which was January 27 for 2008 and was January 15 for 2010

c May data are through physiological maturity, estimated as May 11, 2008 and May 9, 2010

Crop evapotranspiration prediction

The previously developed CGDD $K_{c b}$ curve (Hunsaker et al. 2011) that was used in 2008 poorly predicted the measured daily ET for subtreatments under the FAO $K_{c b}$ method starting in mid-February (Fig. 4a-d). Under prediction of measured ET by the FAO $K_{c b}$ method occurred through mid-March, whereas ET was generally over predicted during April, particularly for the FHB and FLB subtreatments. When ET rate is assessed over the entire
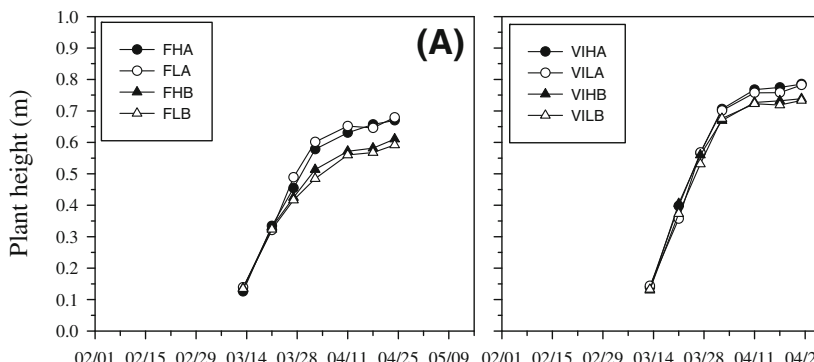

(B)
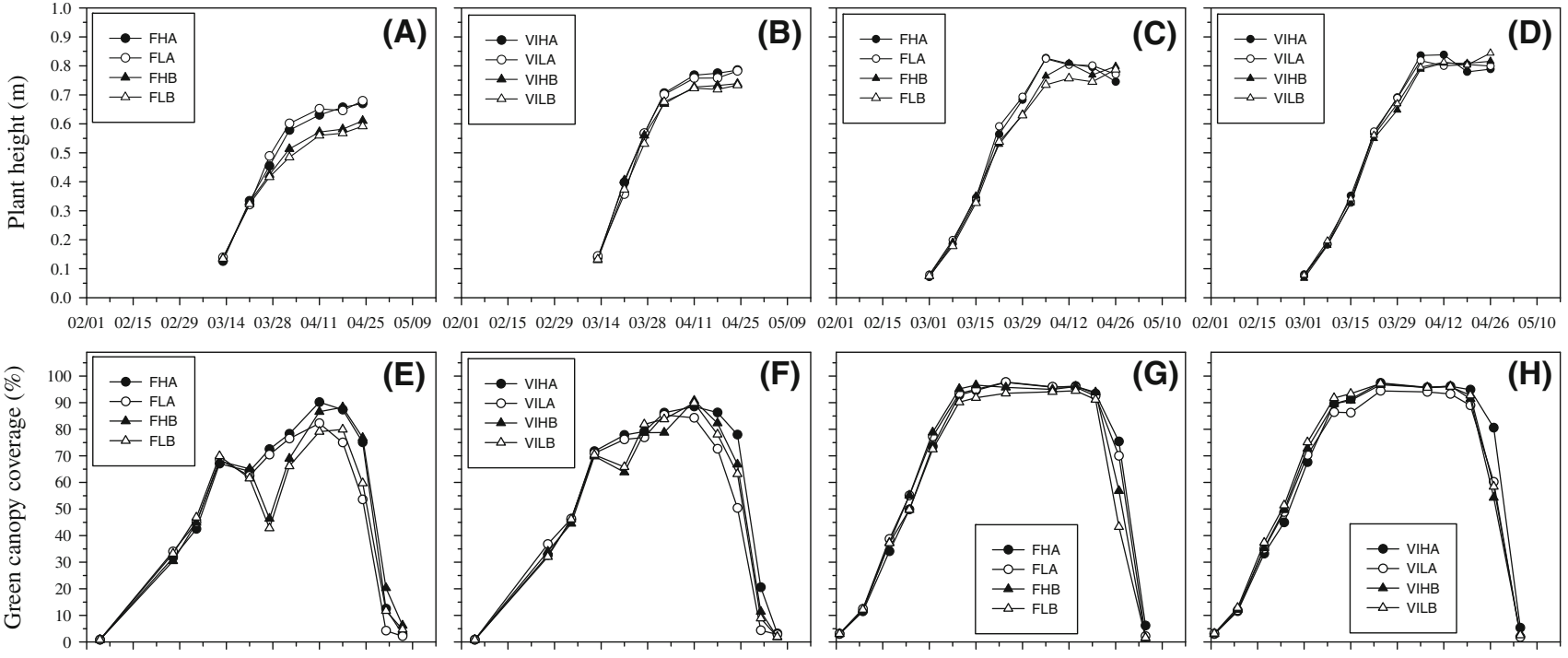

(G)

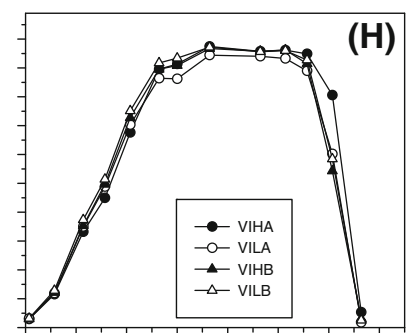

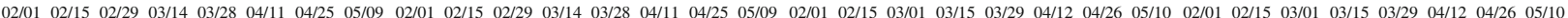

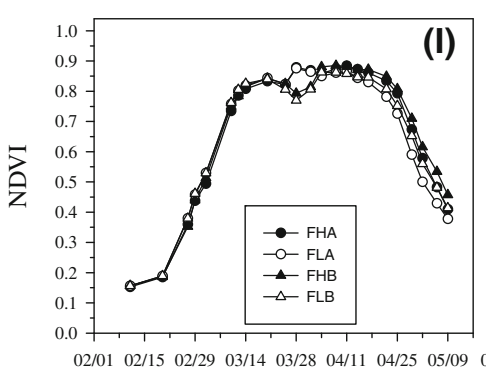

Date 2008

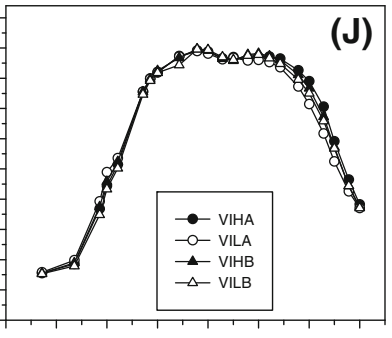

Date 2008
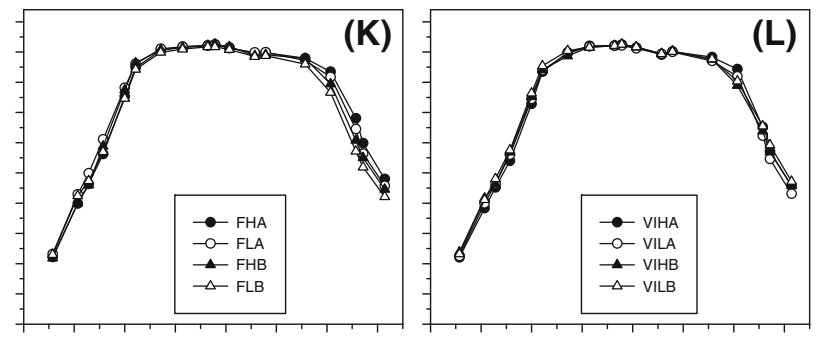

Date 2010

Date 2010

Fig. 3 Seasonal progression of measured camelina crop height (a-d), green canopy cover $(\mathbf{e}-\mathbf{h})$, and normalized difference vegetation index (NDVI, i-l) for the 2008 and 2010 camelina experiments. Each graph in the figure includes means for four subtreatments: either FHA, FLA, FHB, and FLB or VIHA, VILA, VIHB, and VILB 

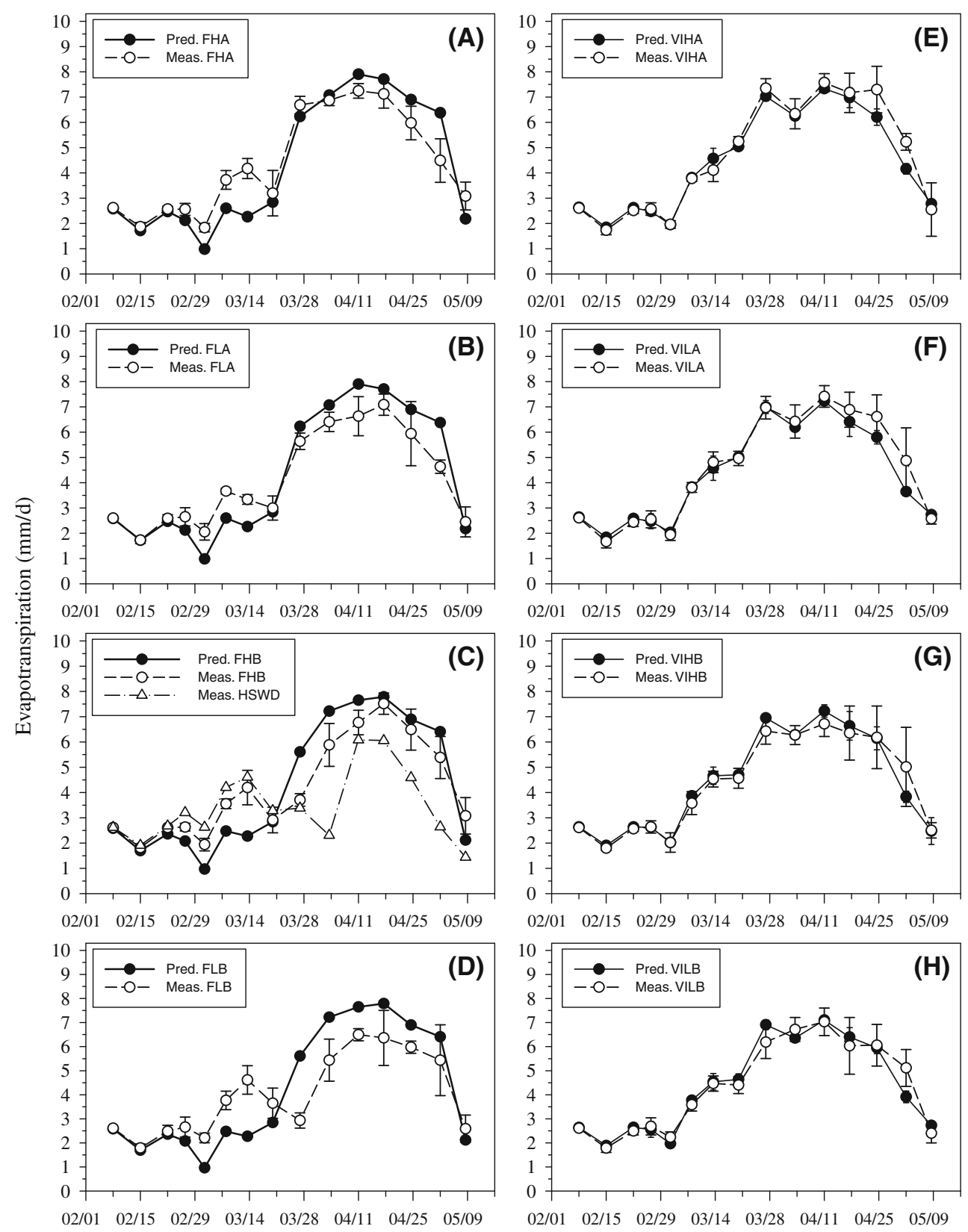

Date 2008

Fig. 4 Mean predicted and mean measured crop evapotranspiration (ET) rates with time for subtreatment FHA (a), FLA (b), FHB (c), FLB (d), VIHA (e), VILA (f), VIHB (g), and VILB (h) in the 2008

season, the prediction and measured ET patterns for the FAO subtreatments tend to offset, ultimately resulting in predicted mean ET rates that were not significantly different than that for measured ET according to paired $t$ tests (Table 4). However, the ET prediction errors for FAO subtreatments were large, $17-28 \%$ as assessed using the MAPE, and the goodness of fit between measured and predicted (using the Nash-Sutcliffe $E$ ) was relatively low. On the other hand, predicted ET for the VI subtreatments experiment. Error bars about the means indicate the standard deviation. The average measured ET rates with time for the HSWD plots are shown in $\mathbf{c}$

was well-matched to the measured ET trends throughout most of the season (Fig. 4d-h). The ET predictions for VIHA and VILA had a low bias $\left(0.16-0.17 \mathrm{~mm}^{-1 a y}{ }^{-1}\right)$, that is, significantly lower than measured mean ET (Table 4). However, the overall prediction errors for the VI subtreatments were not high $(<10 \%)$ and goodness of fit was adequate (Table 4).

As mentioned earlier, all plots in the experiment were irrigated with equal amounts of water on March 7 
Table 4 Summary of mean and standard deviation (SD) for predicted and measured evapotranspiration for subtreatments and comparative statistical analyses results for the 2008 and 2010 camelina experiments in Maricopa, Arizona

\begin{tabular}{|c|c|c|c|c|c|c|c|c|c|c|}
\hline \multirow[t]{2}{*}{ Subtreatment } & \multicolumn{2}{|c|}{ Predicted $\left(\mathrm{mm} \mathrm{day}^{-1}\right)$} & \multicolumn{2}{|c|}{ Measured $\left(m m\right.$ day $\left.^{-1}\right)$} & \multicolumn{2}{|c|}{ Difference $^{\mathrm{a}}\left(\mathrm{mm}\right.$ day $\left.^{-1}\right)$} & \multirow[t]{2}{*}{ MAE $\left(\mathrm{mm} \mathrm{day}^{-1}\right)$} & \multirow[t]{2}{*}{ MAPE $(\%)$} & \multirow[t]{2}{*}{ E } & \multirow[t]{2}{*}{$r^{2}$} \\
\hline & Mean & $\mathrm{SD}$ & Mean & $\mathrm{SD}$ & Mean & SD & & & & \\
\hline \multicolumn{11}{|l|}{2008} \\
\hline FHA & 4.13 & 2.5 & 4.27 & 2.0 & -0.16 & 1.0 & 0.74 & 17.3 & 0.75 & 0.84 \\
\hline FLA & 4.13 & 2.5 & 4.03 & 1.9 & 0.10 & 0.9 & 0.73 & 18.2 & 0.74 & 0.88 \\
\hline FHB & 4.06 & 2.4 & 4.07 & 1.9 & -0.01 & 1.1 & 0.84 & 20.5 & 0.66 & 0.80 \\
\hline FLB & 4.06 & 2.4 & 3.93 & 1.7 & 0.13 & 1.4 & 1.11 & 28.2 & 0.32 & 0.65 \\
\hline VIHA & 4.38 & 1.9 & 4.53 & 2.2 & $-0.16^{*}$ & 0.6 & 0.42 & 8.8 & 0.93 & 0.94 \\
\hline VILA & 4.27 & 1.9 & 4.44 & 2.1 & $-0.17 *$ & 0.6 & 0.37 & 8.3 & 0.90 & 0.92 \\
\hline VIHB & 4.31 & 1.9 & 4.25 & 1.9 & 0.06 & 0.7 & 0.41 & 9.6 & 0.87 & 0.88 \\
\hline VILB & 4.27 & 1.8 & 4.25 & 1.9 & 0.02 & 0.6 & 0.41 & 9.7 & 0.89 & 0.89 \\
\hline \multicolumn{11}{|l|}{2010} \\
\hline FHA & 4.78 & 1.5 & 5.22 & 2.0 & $-0.44 * * *$ & 0.7 & 0.67 & 12.8 & 0.82 & 0.90 \\
\hline FLA & 4.78 & 1.5 & 5.02 & 1.9 & $-0.24 *$ & 0.7 & 0.61 & 12.2 & 0.86 & 0.90 \\
\hline FHB & 4.73 & 1.5 & 4.64 & 1.8 & 0.09 & 0.8 & 0.59 & 12.7 & 0.84 & 0.83 \\
\hline FLB & 4.73 & 1.5 & 4.44 & 1.8 & $0.29 * *$ & 0.8 & 0.55 & 12.5 & 0.83 & 0.83 \\
\hline VIHA & 5.10 & 1.9 & 5.24 & 2.1 & -0.14 & 0.6 & 0.47 & 9.0 & 0.90 & 0.91 \\
\hline VILA & 5.07 & 1.8 & 5.23 & 2.0 & $-0.17 * *$ & 0.5 & 0.37 & 7.1 & 0.94 & 0.95 \\
\hline VIHB & 5.10 & 1.7 & 4.84 & 1.8 & $0.26 * *$ & 0.6 & 0.47 & 9.8 & 0.87 & 0.89 \\
\hline VILB & 5.12 & 1.7 & 4.80 & 1.8 & $0.32 * * *$ & 0.6 & 0.52 & 10.0 & 0.84 & 0.88 \\
\hline
\end{tabular}

Statistical parameters are mean absolute error (MAE), mean absolute percent error (MAPE), Nash-Sutcliffe coefficient $(E)$, and coefficient of determination $\left(r^{2}\right)$

$*$, **, and *** indicate mean differences were significantly different from zero at the $0.05,0.01$, and 0.001 probability levels, respectively, according to paired-sample $t$ tests

${ }^{a}$ Differences are predicted minus measured ET

(Table 2). The under prediction of ET for FAO subtreatments in 2008 resulted in irrigations in March that lagged behind that of the VI subtreatments by about a week across both the A and B levels (Table 2). The under prediction of ET for the FAO subtreatments of 2008 also produced under predicted $\mathrm{SWD}_{p}$ from early February through late March (Fig. 5a-d). Beginning about mid-April, predicted and measured $\mathrm{SWD}_{p}$ were in good agreement for all FAO subtreatments, except for FHA, where measured $\mathrm{SWD}_{p}$ remained higher than predicted throughout the season. Measured mean $\mathrm{SWD}_{p}$ one day prior to the four irrigations of the FHA and FLA subtreatments after March 7 was $57.3 \pm 5 \%$ and $48.7 \pm 3 \%$, respectively. The lower measured $\mathrm{SWD}_{p}$ for the FLA compared to FHA corresponded to lower seasonal ET for Low than High $\mathrm{N}$ treatments, which will be reviewed later in the paper. For the less frequent irrigation subtreatments in the FAO $K_{c b}$ method, that is, FHB and FLB, under prediction of measured ET during the early season resulted in a 25-day period before plots were irrigated on March 31. Initial onset of high soil water stress for the FHB and FLB subtreatments is indicated by reduced measured ET rates (3-4 $\left.\mathrm{mm} \mathrm{day}^{-1}\right)$ compared to the FHA rate (6.7 $\mathrm{mm} \mathrm{day}^{-1}$ ) on March 28 (Fig. 4), just prior to FHB and FLB irrigations on March 31. The reduced ET for FHB and FLB, relative to the FHA, persisted into April, which also corresponded to reduced crop heights for the B than A SWD level (Fig. 3a). Because of the greatly reduced measured ET, mean measured $\mathrm{SWD}_{p}$ for the FHB and FLB subtreatments prior to the March 31 irrigation (66 $\pm 3 \%$ and $67 \pm 3 \%$, respectively), that is, was quite close to predicted $65 \% \mathrm{SWD}_{p}$, (Fig. 5c, d). The combined ET and soil water depletion data for the 2008 FHB and FLB subtreatments suggest that once soil water depletion reaches $\approx 60-65 \%$, camelina ET rate will be sufficiently reduced compared to crop ET when $\mathrm{SWD}_{p}$ is lower. The average measured $\mathrm{SWD}_{p}$ for the HSWD plots prior to irrigation on April 8 was $84 \pm 7 \%$. The effect of this level of $\mathrm{SWD}_{p}$ on the camelina ET rate was pronounced (HSWD ET rate shown in Fig. 4c).

For the VI subtreatments of 2008, predicted $\mathrm{SWD}_{p}$ more closely agreed with measured $\mathrm{SWD}_{p}$ (Fig. $5 \mathrm{e}-\mathrm{h}$ ), owing to 

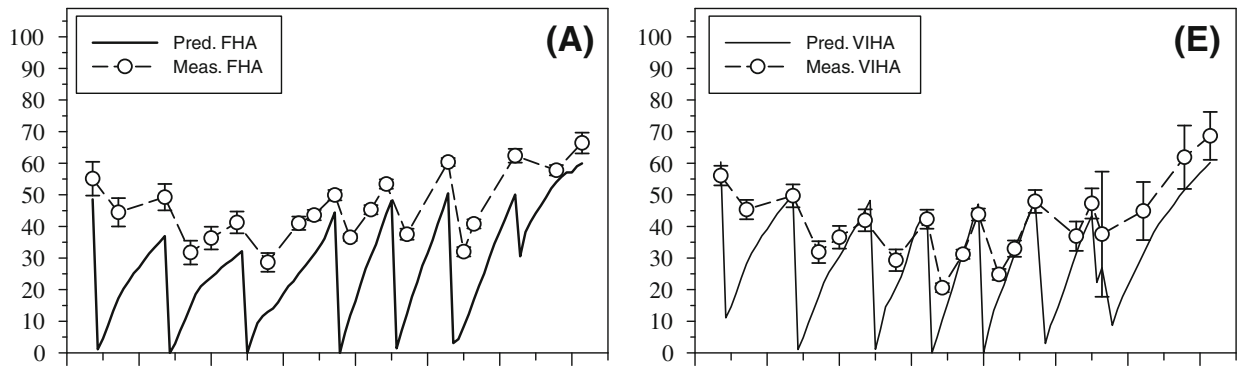

$\begin{array}{llllllll}02 / 01 & 02 / 15 & 02 / 29 & 03 / 14 & 03 / 28 & 04 / 11 & 04 / 25 & 05 / 09\end{array}$

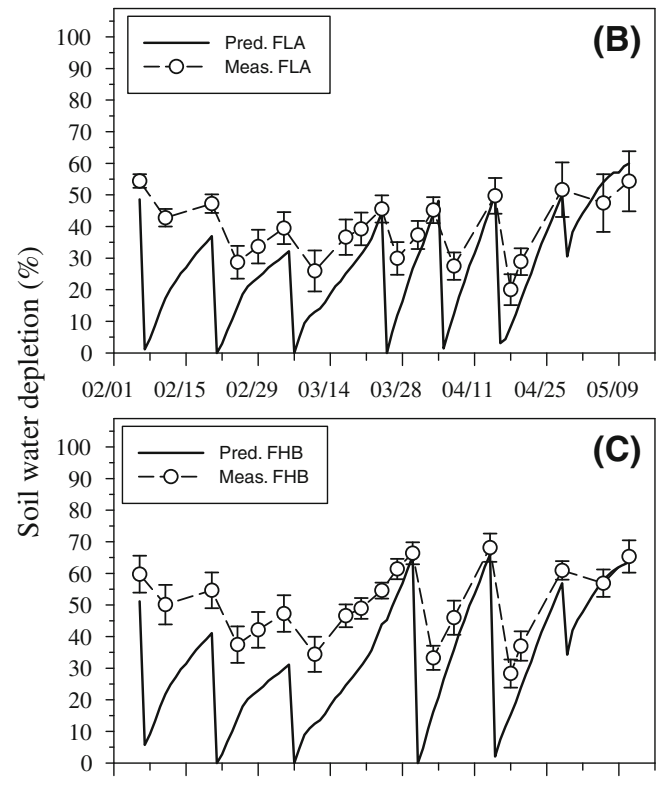

$\begin{array}{llllllll}02 / 01 & 02 / 15 & 02 / 29 & 03 / 14 & 03 / 28 & 04 / 11 & 04 / 25 & 05 / 09\end{array}$

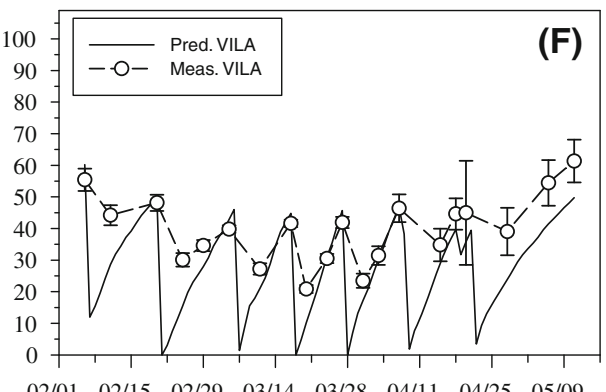

$\begin{array}{llllllll}02 / 01 & 02 / 15 & 02 / 29 & 03 / 14 & 03 / 28 & 04 / 11 & 04 / 25 & 05 / 09\end{array}$

$\begin{array}{llllllll}02 / 01 & 02 / 15 & 02 / 29 & 03 / 14 & 03 / 28 & 04 / 11 & 04 / 25 & 05 / 09\end{array}$
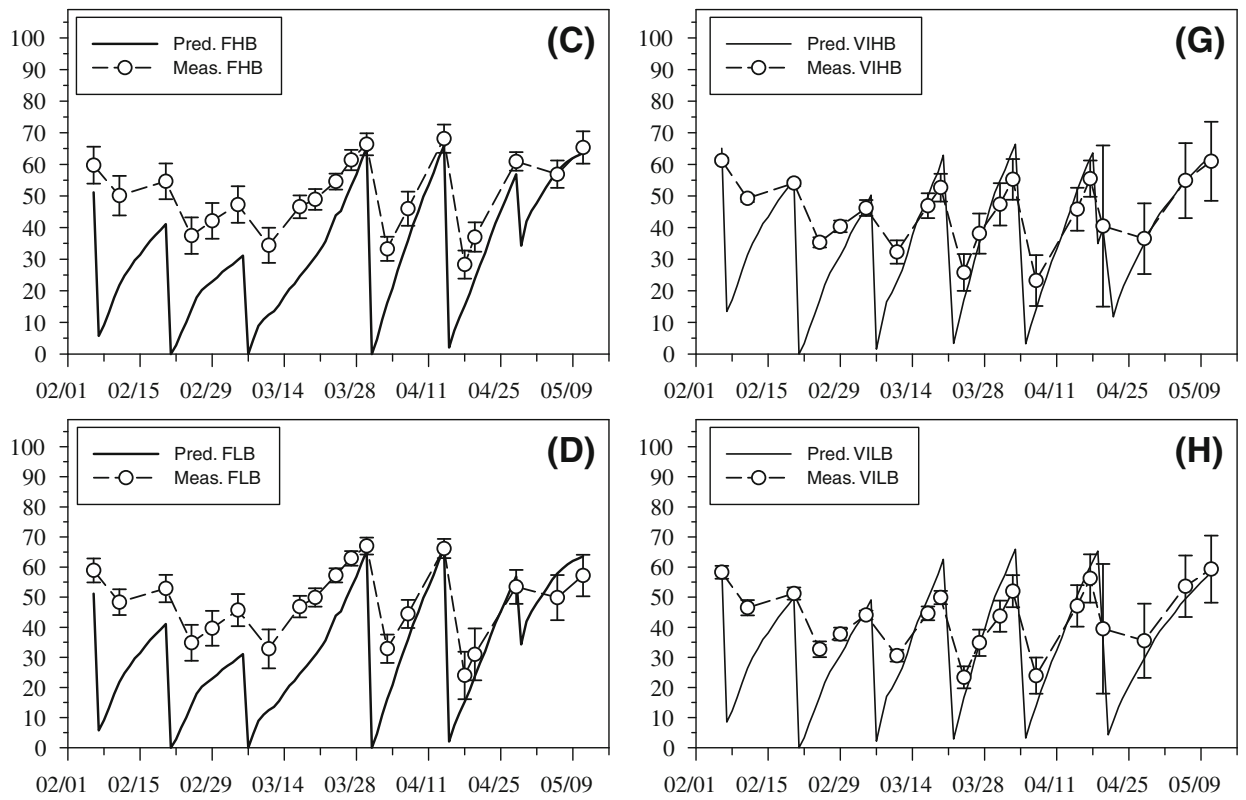

$\begin{array}{llllllll}02 / 01 & 02 / 15 & 02 / 29 & 03 / 14 & 03 / 28 & 04 / 11 & 04 / 25 & 05 / 09\end{array}$

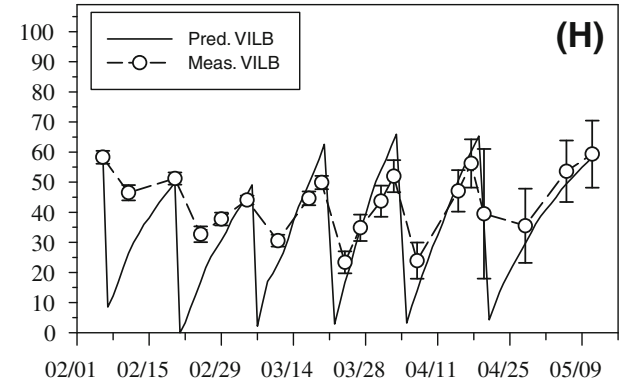

Date 2008

Fig. 5 Mean predicted and mean measured soil water depletion with time for subtreatment FHA (a), FLA (b), FHB (c), FLB (d), VIHA (e), VILA (f), VIHB (g), and VILB (h) in the 2008 experiment. Error bars about the measured means indicate the standard deviation

better predicted ET than for subtreatments under the FAO method. The increasing standard deviation (SD) about the mean $\mathrm{SWD}_{p}$ for the VI subtreatments starting on March 24 for VIHB and VILB and starting on April 7 for VIHA and VILA treatments corresponded to the time that plot replicates within a particular subtreatment were no longer on the same irrigation schedule. For the four scheduled irrigations for the VIHA and VILA subtreatment plots, the mean measured $\mathrm{SWD}_{p}$ one day prior to irrigation was $47 \pm 5 \%$ and $46 \pm 6 \%$, respectively. One day prior to the three scheduled irrigations for the VIHB and VILB subtreatment plots, mean measured $\mathrm{SWD}_{p}$ was only $58 \pm 4 \%$ and $56 \pm 6 \%$, respectively. Thus, mean measured $\mathrm{SWD}_{p}$ at irrigation for the VIHB and VILB subtreatments was similar to FHA, but was less than that for the FHB and FLB subtreatments prior to their irrigations.

Before conducting the 2010 camelina experiment, it was desired to develop an updated CGDD $K_{c b}$ model to improve ET prediction over that obtained with the FAO $K_{c b}$ method in 2008. The updated model, which was used for the FAO $K_{c b}$ method in the 2010 experiment, was developed using back-calculated $K_{c b}$ data derived in the 
2008 experiment. The $K_{c b}$ data used to fit the new model were limited to only those subtreatment plots that were under the High $\mathrm{N}$ treatment level, achieved seed yield of at least $1,600 \mathrm{~kg} \mathrm{ha}^{-1}$, and were not subject to ET reduction, that is, plots within the FHB subtreatment. As used for the original model from Hunsaker et al. (2011), the updated $K_{c b}$ model was a sixth-order sinusoidal regression model driven by CGDD following procedures presented by Fox et al. (1992). The model forces a zero $K_{c b}$ value at the beginning of the season, that is, at $0{ }^{\circ} \mathrm{C} \mathrm{d}$. The model also requires an estimate of the total CGDD for the crop to reach phenological growing season, which was estimated to be $1,300{ }^{\circ} \mathrm{C}$ d for the 2008 season. The updated $K_{c b}$ model is presented along with the original model used for 2008 in Fig. 6. The regression results were

$$
\begin{aligned}
\mathrm{K}_{\mathrm{cb}}= & 1.09(\sin X)-0.176(\sin 2 X)+0.0175(\sin 3 X) \\
& -0.086(\sin 4 X)+0.036(\sin 5 X)+0.021(\sin 6 X)
\end{aligned}
$$

where $X$ is $\left(\mathrm{CGDD}^{*} \Pi\right) / 1,300$. The $r^{2}$ was 0.96 .

The updated CGDD-based $K_{c b}$ model improved daily crop ET prediction for all FAO subtreatments during the early season of 2010 (Fig. 7a-d) compared to the 2008 (Fig. 4a-d). However, there was notable under prediction of ET during April and early May for the FHA subtreatment and to a lesser extent for FLA. Measured ET during April and May was decreased for FHB and FLB relative to the A SWD level subtreatments, similar to 2008 ET trends. In general, the measured ET for FHB and FLB was somewhat over predicted during April and May, but the overprediction was much less extensive than that for FHB and FLB in the latter months of 2008.

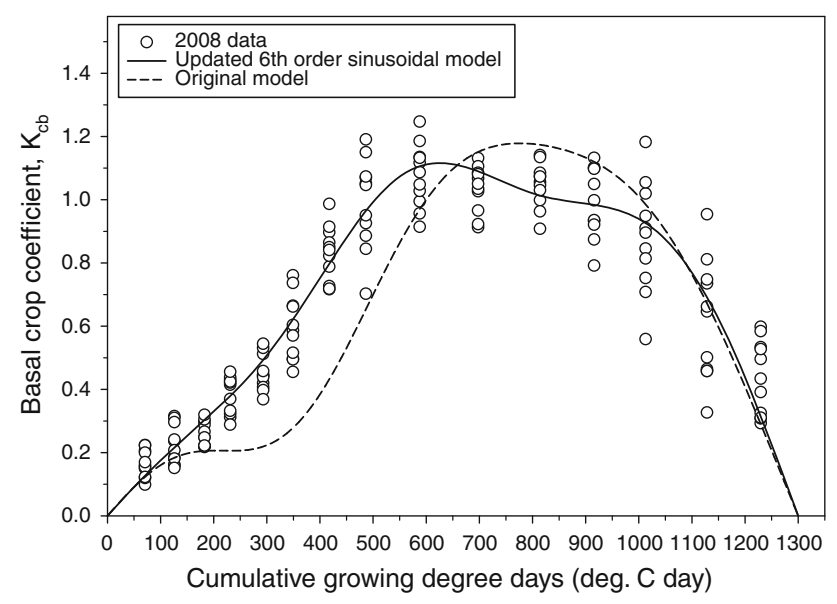

Fig. 6 Updated camelina basal crop coefficient $\left(K_{c b}\right)$ model expressed as a sixth-order function of cumulative growing degree days. The 2008 data used to develop the model are shown as the open circles. The original $K_{c b}$ model from Hunsaker et al. (2011) is shown for comparison
For the VI subtreatments of 2010, predicted and measured ET trends appeared well-matched (Fig. 7e-h), as they had in 2008.

Differences between predicted and measured ET were significant for all FAO subtreatments, except FHB (Table 4). However, the updated $K_{c b}$ model was deemed an improvement in ET prediction for the FAO $K_{c b}$ method in 2010 when considering that the prediction errors for 2010 decreased to $12-13 \%$ compared with MAPD of 17-28\% in 2008. The $E$ coefficients (Table 4) for 2010 were also higher for all FAO subtreatments than in 2008, indicting better agreement with measured ET. For the VIHA and VILA treatments, mean ET rate was slightly under predicted $\left(<0.17 \mathrm{~mm} \mathrm{day}^{-1}\right)$, whereas it was over predicted by $0.26-0.32 \mathrm{~mm} \mathrm{day}^{-1}$ for the VIHB and VILB treatments, respectively (Table 4). The MAPE for the VI subtreatments (7-10\%) and the $E$ coefficient (0.84-0.94) in 2010 indicted low prediction errors and relatively high goodness of fit, as in 2008 for the VI subtreatments.

As was the case for ET, predicted $\mathrm{SWD}_{p}$ using the updated FAO $K_{c b}$ method was substantially improved in 2010 (Fig. 8a-d). Following the irrigation of all plots on February 26, predicted irrigation scheduling for FHA and FLA lagged behind VIHA and VILA by only 2-4 days until mid-to-late April (Table 2). Likewise, FHB and FLB irrigation scheduling lagged behind VIHB and VILB by 4-5 days for the season. Unlike the 2008 season, in which measured $\mathrm{SWD}_{p}$ greatly exceeded predicted $\mathrm{SWD}_{p}$ for FAO subtreatments during the first half of the season, measured $\mathrm{SWD}_{p}$ for the 2010 FAO subtreatments was closely predicted. For the four scheduled irrigations of FHA and FLA in 2010, mean measured $\mathrm{SWD}_{p}$ for FHA and FLA was $46 \pm 6 \%$ and $47 \pm 5 \%$, respectively. For the FHB and FLB subtreatments, the mean measured $\mathrm{SWD}_{p}$ one day prior to the three scheduled irrigations was $58 \pm 3 \%$ and $62 \pm 2 \%$, respectively. Predicted and measured $\mathrm{SWD}_{p}$ trends agreed well for the $2010 \mathrm{VI}$ subtreatments (Fig. 8e-h), as they did in 2008. The mean measured $\mathrm{SWD}_{p}$ one day prior to the four scheduled irrigations for VIHA and VILA in 2010 was $42 \pm 5 \%$ and $40 \pm 4 \%$, respectively, whereas that measured one day prior to the three scheduled irrigations for VIHB and VILA was $60 \pm 4 \%$ and $58 \pm 3 \%$, respectively. Thus, the measured $\mathrm{SWD}_{p}$ for all eight subtreatments in 2010 was lower by about 5-10 \% than that for the same subtreatment in 2008. Even the averaged $\mathrm{SWD}_{p}$ for the HSWD plots measured one day prior to irrigation in 2010 $(70 \pm 3 \%)$ was much lower than that prior to the 2008 irrigation of the HSWD plots $(84 \pm 7 \%)$. However, as in 2008, the effects of higher $\mathrm{SWD}_{p}$ for the HSWD plots in 2010 did reduce the ET rate considerably (Fig. 7c) compared to the ET rates for subtreatments under the A and B SWD levels. 


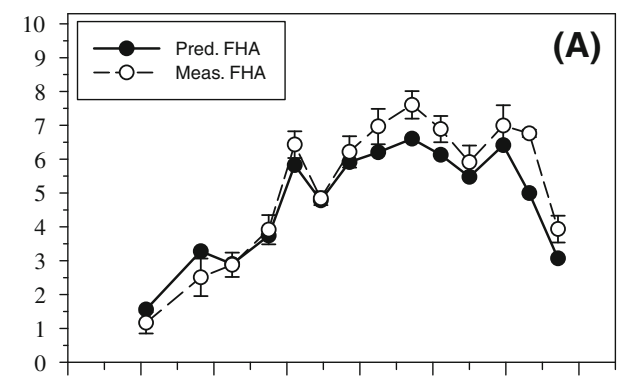

$\begin{array}{llllllll}02 / 01 & 02 / 15 & 03 / 01 & 03 / 15 & 03 / 29 & 04 / 12 & 04 / 26 & 05 / 10\end{array}$

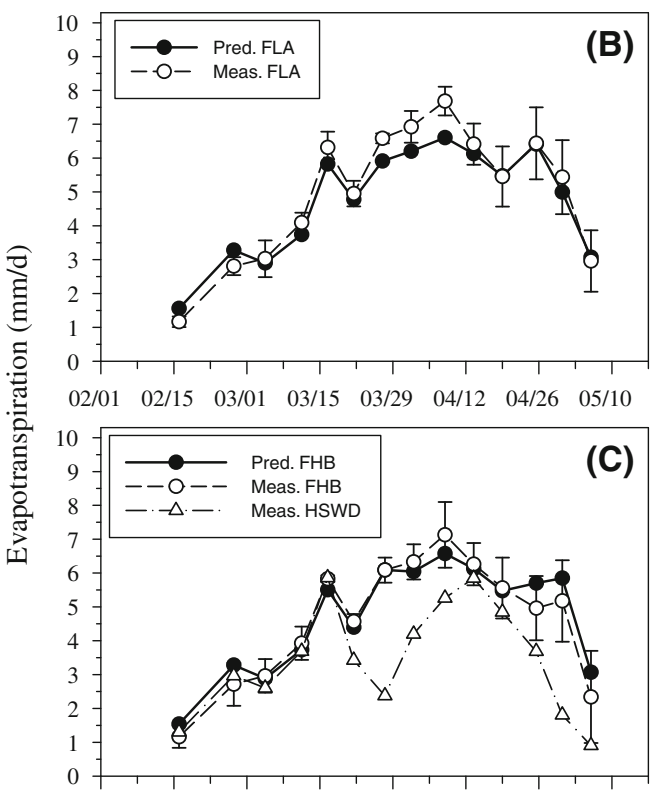

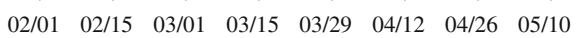

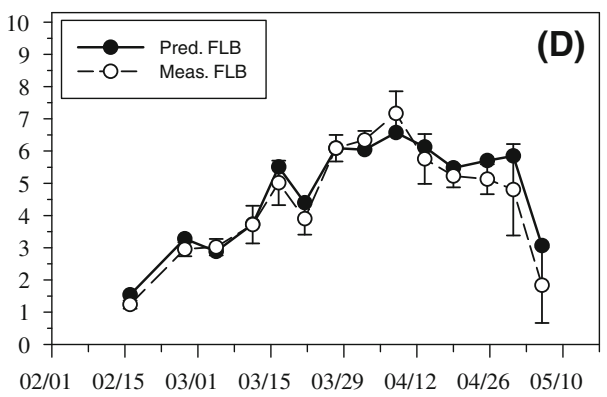

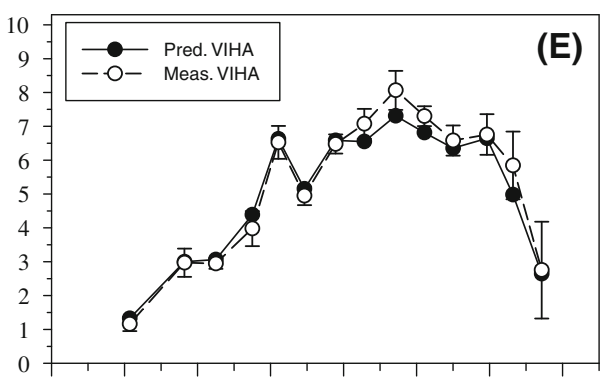

$\begin{array}{llllllll}02 / 01 & 02 / 15 & 03 / 01 & 03 / 15 & 03 / 29 & 04 / 12 & 04 / 26 & 05 / 10\end{array}$
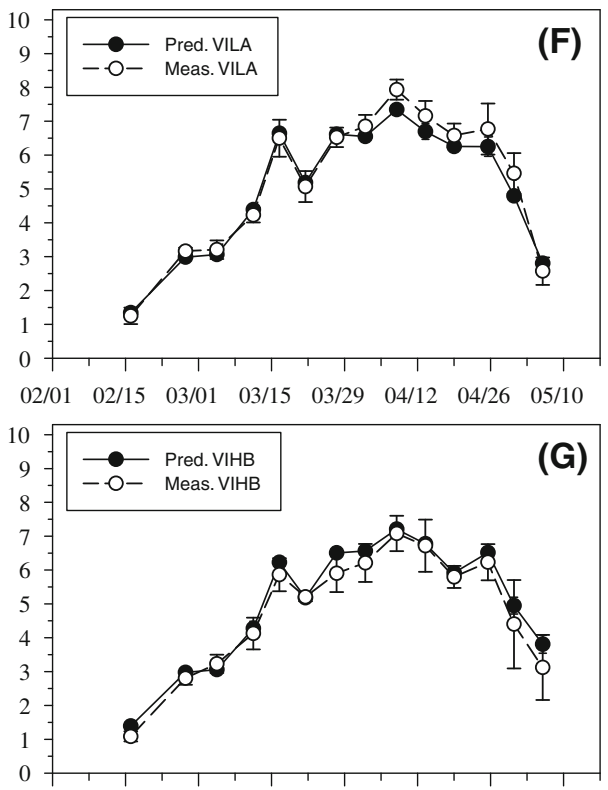

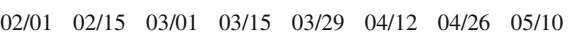

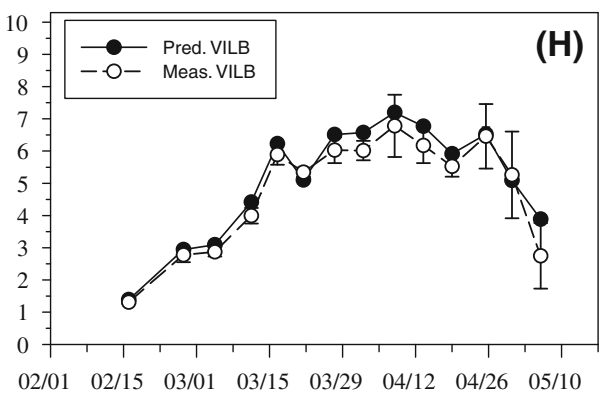

Date 2010

Fig. 7 Mean predicted and mean measured crop evapotranspiration (ET) rates with time for subtreatment FHA (a), FLA (b), FHB (c), FLB (d), VIHA (e), VILA (f), VIHB (g), and VILB (h) in the 2010

Treatment effects on crop water use and yield

The differences noted for 2008 in the ET prediction between the two $K_{c b}$ methods affected irrigation scheduling, which resulted in more seasonal irrigation water applied for the VI than the FAO method (Table 5). Mean total water applied (irrigation plus rainfall) was $27 \mathrm{~mm}$ greater for the VI than the FAO method. Seasonal irrigation and total water applied in 2008 were also significantly experiment. Error bars about the means indicate the standard deviation. The average measured ET rates with time for the HSWD treatment are shown in $\mathbf{c}$

greater for the A than B SWD levels. Different total seasonal water applications between $K_{c b}$ methods and between SWD levels also corresponded to significantly greater seasonal crop ET means for the VI method $(459 \mathrm{~mm})$ than FAO (427 mm) and for the A SWD level $(453 \mathrm{~mm})$ than B (433 mm). The effect of $\mathrm{N}$ level on seasonal ET fell just short of significance $(p=0.06)$ in 2008. As expected, the HSWD plots had substantially lower seasonal ET (352 $\mathrm{mm})$ than main treatments (Table 5). Although mean 
Fig. 8 Mean predicted and mean measured soil water depletion with time for subtreatment FHA (a), FLA (b), FHB (c), FLB (d), VIHA (e), VILA (f), VIHB (g), and VILB (h) in the 2010 experiment. Error bars about the measured means indicate the standard deviation
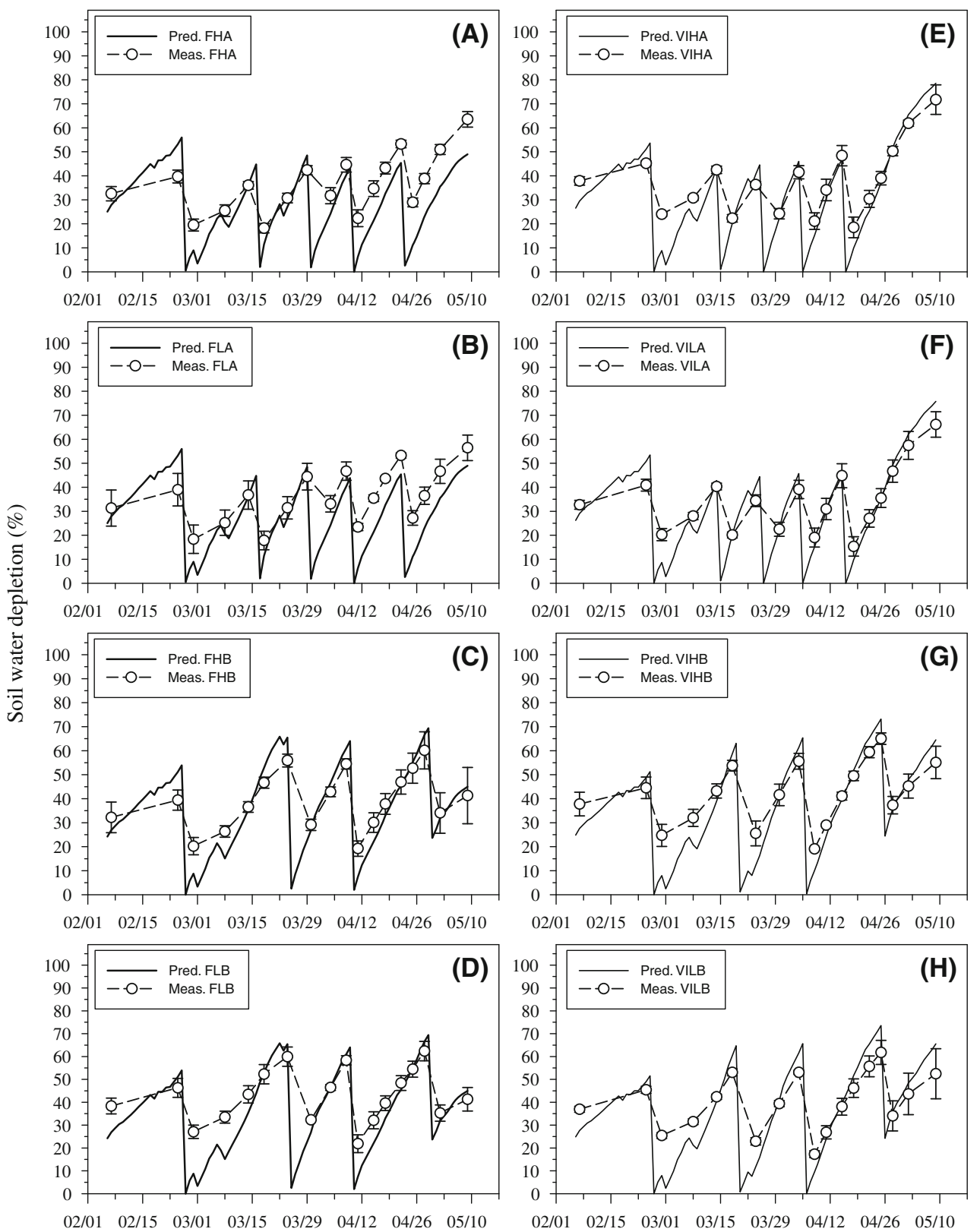

$\begin{array}{llllllll}02 / 01 & 02 / 15 & 03 / 01 & 03 / 15 & 03 / 29 & 04 / 12 & 04 / 26 & 05 / 10\end{array}$

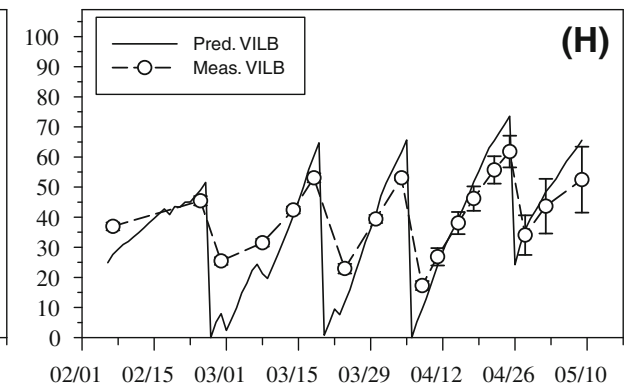

Date 2010 seed yield was $7 \%$ greater for the VI than FAO method $\left(1,638\right.$ vs. $\left.1,527 \mathrm{~kg} \mathrm{ha}^{-1}\right)$, the yield difference was not statistically significant. Similarly, seed yields were $7 \%$ higher for the High than Low $\mathrm{N}$ level, but the difference was also not significant. As expected, mean seed yield for the HSWD treatment was quite low $\left(602 \mathrm{~kg} \mathrm{ha}^{-1}\right)$. As with seed yield, treatment WUE means was not significant. However, seed oil contents were found to be greater for the VI than FAO method, greater for the Low than High $\mathrm{N}$ level, and not different between SWD levels. The seed oil content averaged $45 \%$ over all main treatments, somewhat higher than the oil content of camelina seed reported by others (e.g., Zubr 1997; Berti et al. 2011). Total N content of the camelina seed for 2008 averaged $4.1 \%$ over all main treatments. Unlike the seed oil content results, $\mathrm{N}$ content of the seed was significantly greater for the FAO than VI method, significantly greater for the High than Low $\mathrm{N}$ Level, and significantly greater for the B than A level of SWD. Statistical analysis results for the data presented in Table 5 revealed that interactions between treatment effects were not significant in 2008.

For 2010, there were no differences in seasonal irrigation or total water applied to treatments (Table 5). However, as in 2008, seasonal ET was again greater for the VI 
Table 5 Main treatment means for measured seasonal irrigation water applied, seasonal total water applied (irrigation plus rainfall), seasonal crop evapotranspiration, final seed yield, water use efficiency, and seed oil content for the 2008 and 2010 experiments

\begin{tabular}{|c|c|c|c|c|c|c|c|}
\hline \multirow[t]{2}{*}{ Measurement } & \multicolumn{2}{|c|}{$K_{c b}$ method } & \multicolumn{2}{|c|}{ Nitrogen level } & \multicolumn{2}{|c|}{ SWD level } & \multirow[t]{2}{*}{ HSWD } \\
\hline & FAO & VI & $\mathrm{H}$ & $\mathrm{L}$ & A & $\mathrm{B}$ & \\
\hline \multicolumn{8}{|l|}{2008 experiment } \\
\hline Irrigation applied (mm) & $437 b$ & $464 a$ & $450 \mathrm{a}$ & $451 \mathrm{a}$ & $455 \mathrm{a}$ & $445 b$ & 307 \\
\hline Total water applied (mm) & $467 b$ & $494 a$ & $480 \mathrm{a}$ & $481 \mathrm{a}$ & $485 \mathrm{a}$ & $475 b$ & 337 \\
\hline Crop evapotranspiration (mm) & $427 b$ & $459 a$ & $449 a$ & $437 \mathrm{a}$ & $453 a$ & $433 b$ & 352 \\
\hline Seed yield $\left(\mathrm{kg} \mathrm{ha}^{-1}\right)$ & $1,527 \mathrm{a}$ & $1,638 \mathrm{a}$ & $1,638 \mathrm{a}$ & $1,527 \mathrm{a}$ & $1,580 \mathrm{a}$ & $1,585 \mathrm{a}$ & 602 \\
\hline Water use efficiency $\left(\mathrm{kg} \mathrm{m}^{-3}\right)$ & $0.36 \mathrm{a}$ & $0.36 \mathrm{a}$ & $0.36 \mathrm{a}$ & $0.35 \mathrm{a}$ & $0.35 \mathrm{a}$ & $0.37 \mathrm{a}$ & 0.17 \\
\hline Seed oil content $(\%)$ & $44.0 \mathrm{~b}$ & $46.5 \mathrm{a}$ & $44.3 b$ & $46.2 \mathrm{a}$ & $45.7 \mathrm{a}$ & $44.8 \mathrm{a}$ & 40.2 \\
\hline \multicolumn{8}{|l|}{2010 experiment } \\
\hline Irrigation applied (mm) & $409 a$ & $410 \mathrm{a}$ & $409 a$ & $410 \mathrm{a}$ & $408 \mathrm{a}$ & $411 \mathrm{a}$ & 249 \\
\hline Total water applied (mm) & $500 \mathrm{a}$ & $501 \mathrm{a}$ & $500 \mathrm{a}$ & $501 \mathrm{a}$ & $499 a$ & $502 \mathrm{a}$ & 340 \\
\hline Crop evapotranspiration (mm) & $445 b$ & $461 \mathrm{a}$ & $457 \mathrm{a}$ & $449 \mathrm{a}$ & $472 \mathrm{a}$ & $434 b$ & 350 \\
\hline Seed yield $\left(\mathrm{kg} \mathrm{ha}^{-1}\right)$ & $1,575 \mathrm{a}$ & $1,514 \mathrm{a}$ & $1,539 \mathrm{a}$ & $1,550 \mathrm{a}$ & $1,596 \mathrm{a}$ & $1,492 \mathrm{a}$ & 1,178 \\
\hline Water use efficiency $\left(\mathrm{kg} \mathrm{m}^{-3}\right)$ & $0.35 \mathrm{a}$ & $0.33 \mathrm{a}$ & $0.34 \mathrm{a}$ & $0.35 \mathrm{a}$ & $0.34 \mathrm{a}$ & $0.34 \mathrm{a}$ & 0.33 \\
\hline Seed oil content $(\%)$ & $44.8 \mathrm{a}$ & $45.5 \mathrm{a}$ & $44.7 \mathrm{a}$ & $45.6 \mathrm{a}$ & $46.0 \mathrm{a}$ & $44.3 b$ & 40.3 \\
\hline \multicolumn{8}{|l|}{ Experiments combined } \\
\hline Irrigation applied (mm) & $423 b$ & $437 \mathrm{a}$ & $430 \mathrm{a}$ & $430 \mathrm{a}$ & $432 \mathrm{a}$ & $428 \mathrm{a}$ & 278 \\
\hline Total water applied (mm) & $483 b$ & $497 \mathrm{a}$ & $490 \mathrm{a}$ & $490 \mathrm{a}$ & $492 \mathrm{a}$ & $488 \mathrm{a}$ & 338 \\
\hline Crop evapotranspiration (mm) & $436 b$ & $460 \mathrm{a}$ & $453 a$ & $443 b$ & $463 a$ & $433 b$ & 351 \\
\hline Seed yield $\left(\mathrm{kg} \mathrm{ha}^{-1}\right)$ & $1,551 \mathrm{a}$ & $1,576 \mathrm{a}$ & $1,589 \mathrm{a}$ & $1,538 \mathrm{a}$ & $1,588 \mathrm{a}$ & $1,539 \mathrm{a}$ & 890 \\
\hline Water use efficiency $\left(\mathrm{kg} \mathrm{m}^{-3}\right)$ & $0.36 \mathrm{a}$ & $0.34 \mathrm{a}$ & $0.35 \mathrm{a}$ & $0.35 \mathrm{a}$ & $0.34 \mathrm{a}$ & $0.35 \mathrm{a}$ & 0.25 \\
\hline Seed oil content $(\%)$ & $44.4 \mathrm{~b}$ & $46.0 \mathrm{a}$ & $44.4 \mathrm{~b}$ & $45.9 \mathrm{a}$ & $45.9 \mathrm{a}$ & $44.5 b$ & 40.2 \\
\hline
\end{tabular}

For each experiment and for combined experiments, treatment means for measured parameters in the rows below either $K_{c b}$ method, nitrogen level, or SWD level with the same letter are not significantly different

method $(461 \mathrm{~mm})$ than FAO $(445 \mathrm{~mm})$, greater for the A SWD level (472) than B (434), and not significantly different between $\mathrm{N}$ levels. Thus, while total water applied in 2010 was essentially equal for the two $K_{c b}$ methods and for the two SWD levels, the effects of different irrigation scheduling patterns between methods and between SWD levels over the season likely caused differences in seasonal ET. As in 2008, seasonal ET for the HSWD plots in 2010 $(350 \mathrm{~mm})$ was much lower than that for the main treatments (Table 5). Differences in seed yield between main treatments were again not significant in 2010. The seed yield for the VIHB subtreatment was extremely variable among plot replicates, where two VIHB plots had the lowest yields ( 659 and $853 \mathrm{~kg} \mathrm{ha}^{-1}$ ) among all main plots. However, the interaction between $K_{c b}$ method and SWD level was just short of significance $(p=0.06)$. The WUE was not significantly affected by treatments, as in 2008 . However, seed oil content was greater for the A than B level, but the effects of other treatments were not significant. Seed oil contents for treatments in 2010, 44-46\%, were similar to those in 2008 . Total $\mathrm{N}$ for all main treatments averaged $4.1 \%$ for 2010 , which was the same average obtained for 2008. There were no statistical differences between treatments for total $\mathrm{N}$.

An unexpected result from the 2010 experiment was that average seed yield for the HSWD plots was nearly double $\left(1,178 \mathrm{~kg} \mathrm{ha}^{-1}\right)$ that of the HSWD plot average in 2008 . An explanation was that the maximum soil water depletion experienced by the HSWD plots in 2008 (84 \%) had a much greater impact on seed yield than it did under the less extreme soil water depletion experienced in 2010 (70 \%). Thus, while seed yield nearly doubled for the HSWD plots in 2010 than 2008, the soil water depletion experienced by HSWD plots in 2010 reduced ET to about the same extent as that in 2008 (i.e., $\approx 30 \%$ seasonal ET reduction from seasonal ET of the VI treatment).

Combined statistical analyses of the two experiments indicated that the covariance parameter estimate for year did not have significance during the Proc Mixed analysis for each of measured variables in Table 5. Two-year analyses revealed only a few instances of significant treatment effects (Table 5). These included differences between seasonal irrigation, total water applied, and seasonal ET between the VI and FAO methods as found earlier for both 
years, and seasonal ET differences between the A and B levels, also found for both years. A different result obtained from the two-year analyses was that the seasonal ET was also deemed significantly greater for the High than Low N level. Mean seed yield from all main treatment plots was $1,545 \mathrm{~kg} \mathrm{ha}^{-1}$ in 2010 compared with $1,583 \mathrm{~kg} \mathrm{ha}^{-1}$ in 2008. Mean seed yield in 2010 was $3 \%$ higher for the FAO method but was $7.5 \%$ lower for the VI method compared to yields in 2008. As found earlier, there were no treatment effects or interactions among treatments for seed yield. Seed yield differences due to within-season $\mathrm{N}$ application levels may have been suppressed somewhat by the relatively high residual soil $\mathrm{N}$ contents that were measured at the beginning of each experiment. Nevertheless, the 2010 data indicate that camelina seed yields may not increase with a total $\mathrm{N}$ application above $100 \mathrm{~kg} \mathrm{~N} \mathrm{ha}^{-1}$, as suggested by Zubr's data (Zubr 1997). Two-year analysis indicated that seed oil contents were greater for the VI than FAO method, greater for the Low than High $\mathrm{N}$ level, and greater for the A than B SWD levels. In contrast, $\mathrm{N}$ content of seed was greater for the FAO than VI method, greater for the B than A SWD level, and not different between $\mathrm{N}$ levels, considering the two-year analysis.

Combining data from both experiments (including data from HSWD plots), seed yields were found to be linearly related to seasonal ET (Fig. 9). Because total water applied was higher than the seasonal ET measured for main treatments (but not HSWD plots), it appears that maximum ET for camelina in Arizona plateaus at about $470-490 \mathrm{~mm}$, which is slightly lower than that reported for camelina grown under irrigation in Nebraska (Hergert et al. 2011). However, the camelina seed yield versus water use function presented by Hergert et al. (2011) had a greater slope $(\approx 7.0)$ than the slope of 5.6 for our Arizona camelina

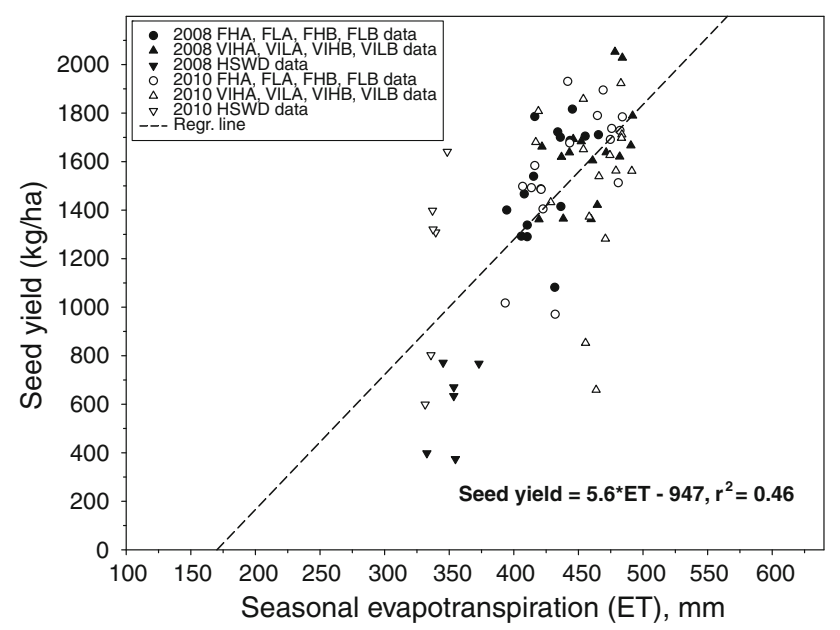

Fig. 9 Camelina seed yield versus seasonal evapotranspiration (ET) for individual subtreatment plots in 2008 and 2010. Linear regression results include the high soil water depletion (HSWD) plots production curve. In terms of seasonal crop water use, the maximum camelina ET in Arizona was considerably lower than that for wheat $(650 \mathrm{~mm}$; Erie et al. 1982), which is traditionally grown in Arizona during the same months as camelina. Mean camelina seed yields for treatments obtained from the experiments in Arizona were considerably higher than those reported in recent studies in the US states of Minnesota (Gesch and Cermak 2011) and Nebraska (Pavlista et al. 2011), though lower than those reported earlier in Canada $\left(\approx 2,000 \mathrm{~kg} \mathrm{ha}^{-1}\right.$ by Gugel and Falk 2006).

\section{Conclusions}

Camelina could become an important alternative energy crop for arid agriculture in the southwestern USA. Irrigation experiments conducted for two years in Arizona revealed that camelina presently has a seed yield of over $1,500 \mathrm{~kg} \mathrm{ha}^{-1}$ when grown from January to May. Moreover, the seed oil contents obtained were quite high, averaging $45 \%$ in the two experiments or about $5 \%$ higher than those previously reported in the literature. The maximum camelina seasonal water use (i.e., ET) obtained was $470-490 \mathrm{~mm}$, making camelina a low water use crop compared with traditional crops, such as spring wheat. Camelina ET was reduced from maximum ET rates when the soil water depletion reached about 60-65\%, though seed yield reduction due to that level of soil water stress was not significant. Thus, camelina seed yield responses appeared to be uniform over a range of soil water depletion levels managed from 45 to $65 \%$ before irrigation was applied. However, the experiments confirmed earlier findings that seed yield will decrease rapidly when soil water depletion reaches about $70 \%$ and beyond. Thus, accurate estimation of camelina ET rates during the season is needed to determine soil water depletion and irrigation scheduling. For this purpose, two basal crop coefficient techniques were developed to estimate camelina ET with the widely applied FAO-56 procedures. A previously developed growing degree-day-based $K_{c b}$ method was updated and validated during the second experiment. The previously developed NDVI-based crop coefficient method was applied in each experiment and provided estimates of ET within 7-10\% of measured ET. There were no observable seed yield differences due to seasonal $\mathrm{N}$ applications that ranged from 69 to $144 \mathrm{~kg} \mathrm{~N} \mathrm{ha}^{-1}$. However, responses to $\mathrm{N}$ applications in these experiments may have been masked due to relatively high residual soil $\mathrm{N}$ contents that averaged $18-25 \mathrm{~kg} \mathrm{NO}-\mathrm{N} \mathrm{ha}^{-1}$. Future work is planned in Arizona to determine camelina yield responses under a greater range in both irrigation and $\mathrm{N}$ level than those used in these experiments. 


\section{References}

Aiken R, Lamm F, Aboukheira AA (2011) Water use of oilseed crops. In Proceedings of the 23rd annual central plains irrigation conference, Feb 22-23, 2011, Burlington, CO, USA, pp 181-189

Allen RG, Pereira LS (2009) Estimating crop coefficients from fraction of ground cover and height. Irrig Sci 28(1):17-34

Allen RG, Pereira LS, Raes D, and Smith M (1998) Crop evapotranspiration: guidelines for computing crop water requirements. FAO Irrigation and Drainage Paper No. 56. FAO, Rome

Bernardo A, Howard-Hildige R, O'Connell B, Nichol R, Ryan J, Rice B, Roche E, Leahy JJ (2003) Camelina oil as a fuel for diesel transport engines. Ind Crops Prod 17(3):191-197

Berti M, Wilckens R, Fischer S, Solis A, Johnson B (2011) Seeding date influence on camelina seed yield, yield components, and oil content in Chile. Ind Crops Prod 34:1358-1365

Brown PW (1989) Accessing the Arizona meteorological network (AZMET) by computer. Extension Report No. 8733. University of Arizona, Tucson, AZ, USA

Brown PW (1991) Normal values of heat unit accumulation for southern Arizona. Extension Report No. 190041. University of Arizona, Tucson, AZ, USA

Budin JT, Breene WM, Putnam DH (1995) Some compositional properties of camelina (Camelina sativa $\mathrm{L}$. Crantz) seeds and oils. J Am Chem Soc 72(3):309-315

Erie LJ, French OF, Bucks DA, Harris K (1982) Consumptive use of water by major crops in the southwestern United States. Conservation Research Report No. 29. USDA, Washington, DC

Fox FA, Scherer T, Slack DC, Clark L (1992) Arizona irrigation schedule (AZSCHED, version 1.01): user's manual. Cooperative extension. University of Arizona, Tucson, AZ, USA

French AN, Hunsaker D, Thorp K, Clarke T (2009) Evapotranspiration over a camelina crop at Maricopa, Arizona. Ind Crops Prod 29(2-3):289-300

Frohlich A, Rice B (2005) Evaluation of Camelina sativa oil as a feedstock for biodiesel production. Ind Crops Prod 21(1):25-31

Gesch RW, Cermak SC (2011) Sowing date and tillage effects on fallseeded camelina in the northern corn belt. Agron J 103(4): 980-987

Gilbertson PK, Johnson BL, Berti MT, Halvorson MA (2007) Seeding date and performance of specialty oilseeds in North Dakota. In: Janick J, Whipkey A (eds) Issues in new crops and new uses. ASHS Press, Alexandria, pp 105-110

Gonzalez-Dugo MP, Mateos L (2008) Spectral vegetation indices for benchmarking water productivity of irrigated cotton and sugarbeet crops. Agric Water Manage 95(1):48-58

Gugel RK, Falk KC (2006) Agronomic and seed quality evaluation of camelina sativa in western Canada. Can J Plant Sci 86: $1047-1058$

Hergert GW, Margheim J, Pavlista A, Burgener P, Lyon D, Hazen A, Martin D, Supalla R, Thompson C (2011) Yields and ET of deficit to fully irrigated canola and camelina. In Proceedings of the 23rd annual central plains irrigation conference, Feb 22-23, 2011, Burlington, CO, USA, pp 190-198

Howell TA, Evett SR, Tolk JA, Schneider AD (2004) Evapotranspiration of full-, deficit-irrigated, and dryland cotton on the Northern Texas High Plains. J Irrig Drain Eng 130(4):277-285

Hunsaker DJ, Pinter PJ Jr, Kimball BA (2005) Wheat basal crop coefficients determined by normalized difference vegetation index. Irrig Sci 24(1):1-14

Hunsaker DJ, Fitzgerald GJ, French AN, Clarke TR, Ottman MJ, Pinter PJ Jr (2007) Wheat irrigation management using multispectral crop coefficients. I. Crop evapotranspiration prediction. Trans ASABE 50(6):2017-2033
Hunsaker DJ, French AN, Clarke TR, El-Shikha DM (2011) Water use, crop coefficients, and irrigation management criteria for camelina production in arid regions. Irrig Sci 29(1):27-43

Jensen ME, Allen RG (2000) Evolution of practical ET estimating methods. In: Evans, RG, Benham BL, Trooien TP (eds) Proceedings of 4th natural irrigation symposium, Phoenix, AZ 14-16 Nov, ASAE St. Joseph, MI, USA, pp 52-65

Martin DL, Gilley JR (1993) Irrigation water requirements. In: Part 623, Nat Eng Handbook, Chapter 2. USDA-SCS, Washington, DC

Moser BR (2010) Camelina (Camelina sativa L.) oil as a biofuels feedstock: golden opportunity or false hope? Lipid Tech 22(12):270-273

Nash JE, Sutcliffe JV (1970) River flow forecasting through conceptual models part $1-$ a discussion of principles. J Hydrol 10(3):282-290

Paul S, Haan PK, Matlock MD, Mukhtar S, Pillia SD (2004) Analysis of the HSPF water quality parameter uncertainty in predicting peak in-stream fecal coliform concentrations. Trans ASAE 47(1):69-78

Pavlista AD, Baltensperger DD (2007) Phenology of oilseed crops for bio-diesel in the high plains. In: Janick J, Whipkey A (eds) Issues in new crops and new uses. ASHS Press, Alexandria, pp 60-63

Pavlista AD, Isbell TA, Baltensperger DD, Hergert GW (2011) Planting date and development of spring-seeded irrigated canola, brown mustard and camelina. Ind Crops Prod 33:451-456

Pilgeram AL, Sands DC, Boss D, Dale N, Wichman D, Lamb P, Lu C, Barrows R, Kirkpatrick M, Thompson B, Johnson DL (2007) Camelina sativa, a Montana omega-3 fatty acid and fuel crop. In: Janick J, Whipkey A (eds) Issues in new crops and new uses. ASHS Press, Alexandria, pp 129-131

Post DF, Mack C, Camp PD, Sulliman AS (1988) Mapping and characterization of the soils on the University of Arizona, Maricopa Agricultural Center. In: Proceedings of hydrology and water resources in Arizona and the Southwest. University of Arizona, Tucson, AZ, USA, pp 49-60

Putnam D, Budin J, Field L, Breene W (1993) Camelina: a promising low-input oilseed. In: Janick J, Simon JE (eds) New crops. Wiley, New York, pp 314-322

Sammis TW, Mapel CL, Lugg DG, Lansford RR, McGucin JT (1985) Evapotranspiration crop coefficients predicted using growingdegree-days. Trans ASAE 28(3):773-780

SAS Institute Inc. (2009) SAS OnlineDoc ${ }^{\circledR}$ 9.2., SAS Institute Inc. Cary, NC, USA

Slack DC, Martin EC, Sheta AE, Fox F Jr, Clark LJ, Ashley RO (1996) Crop coefficients normalized for climatic variability with growing-degree days. In: Camp CR, Sadler EJ, Yoder RE (eds) Proceedings of international conference on evapotranspiration and irrigation scheduling, 3-6 Nov 1996, San Antonio. ASAE, St Joseph, MI, USA

Vollmann J, Moritz T, Kargl C, Baumgartner S, Wagentristl H (2007) Agronomic evaluation of camelina genotypes selected for seed quality characteristics. Ind Crops Prod 26(3):270-277

Wang WC, Chau KW, Cheng CT, Qiu L (2009) A comparison of performance of several artificial intelligence methods for forecasting monthly discharge time series. J Hydrol 374(3-4): 294-306

Zubr J (1997) Oil-seed crop: Camelina sativa. Ind Crops Prod 6(2):113-119

Zubr J (2003) Qualitative variation of Camelina sativa seed from different locations. Ind Crops Prod 17(3):161-169 